Florida International University FIU Digital Commons

$4-1-2016$

\title{
A Study on the Dissolution of Autunite Minerals by Facultative Bacteria in Bicarbonate Media
}

Sandra C. Herrera Landaez

Florida International University, sherr068@fiu.edu

DOI: 10.25148 /etd.FIDC000287

Follow this and additional works at: https://digitalcommons.fiu.edu/etd

Part of the Biology Commons, Environmental Engineering Commons, and the Environmental Microbiology and Microbial Ecology Commons

\section{Recommended Citation}

Herrera Landaez, Sandra C., "A Study on the Dissolution of Autunite Minerals by Facultative Bacteria in Bicarbonate Media" (2016). FIU Electronic Theses and Dissertations. 2437.

https://digitalcommons.fiu.edu/etd/2437 


\title{
FLORIDA INTERNATIONAL UNIVERSITY
}

Miami, Florida

\section{A STUDY ON THE DISSOLUTION OF AUTUNITE MINERALS BY}

FACULTATIVE BACTERIA IN BICARBONATE MEDIA

\author{
A thesis submitted in partial fulfillment of the \\ requirements for the degree of \\ MASTER OF SCIENCE \\ in \\ ENVIRONMENTAL ENGINEERING
}

by

Sandra Carolina Herrera Landaez

2016 
To: Interim Dean Ranu Jung

College of Engineering and Computing

This thesis, written by Sandra Carolina Herrera Landaez, and entitled A Study on the Dissolution of Autunite Minerals by Facultative Bacteria in Bicarbonate Media, having been approved in respect to style and intellectual content, is referred to you for judgment.

We have read this thesis and recommend that it be approved.

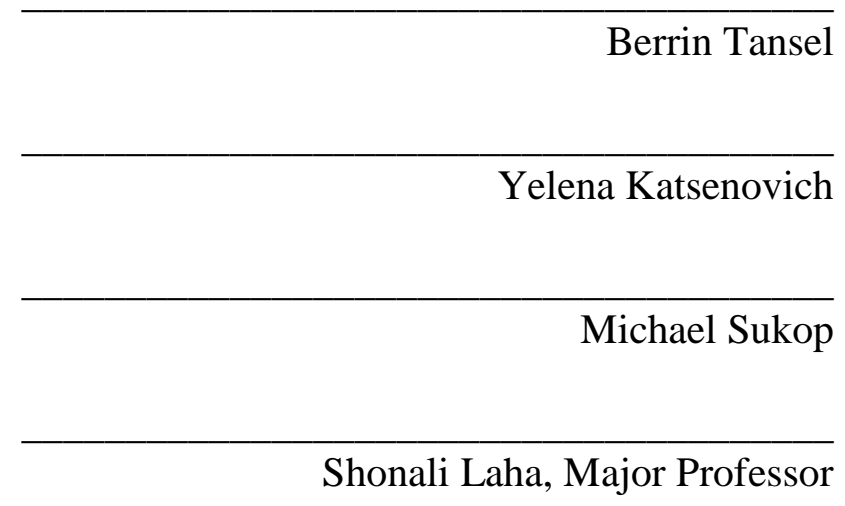

Date of Defense: April 31, 2016

The thesis of Sandra Carolina Herrera Landaez is approved.

Interim Dean Ranu Jung

College of Engineering and Computing

Andrés G. Gil

Vice President for Research and Economic Development and Dean of the University Graduate School

Florida International University, 2016 


\section{DEDICATION}

This work is dedicated to my family that has stood by my side unconditionally throughout my life and to the Department of Energy, Florida International University Science and Technology Workforce Development Program along with its staff, mentors and fellows. Thanks to their guidance, patience and commitment towards education, this project came to its completion. 


\section{ACKNOWLEDGMENTS}

I would like to acknowledge my committee; Drs. Yelena Katsenovich, Shonali Laha, Michael Sukop and Berrin Tansel. My sincere appreciation is extended to Drs. Brady Lee and Hope Lee from Pacific Northwest National Laboratory (PNNL) for providing us with Shewanella Oneidensis MR-1strains and methodology for experiments and being always evailable to dicuss results. I would like to acknowledge the assistance from Drs. Vasileios Anagnostopoulos and Ravi Gudavalli for providing scientific explanations and teaching me laboratory skills. I would like to express my sincere appreciation to Dr. Leonel Lagos, the DOE-FIU Science and Technology Workforce Development Program Director for supporting me throughout this investigation. Funding for this research was provided by US DOE Grant Number: Under Cooperative Agreement No. DE-EM0000598. 
ABSTRACT OF THE THESIS

A STUDY ON THE DISSOLUTION OF AUTUNITE MINERALS BY

FACULTATIVE BACTERIA IN BICARBONATE MEDIA

\author{
by \\ Sandra Carolina Herrera Landaez \\ Florida International University, 2016 \\ Miami, Florida \\ Professor Shonali Laha, Major Professor
}

Uranium (U) is a key contaminant at the Hanford site. The formation of uranylphosphate bearing minerals such as autunite as a result of tripoliphosphate injections has been used as a U immobilization strategy. Bacteria are known as key factors governing the fate and transport of soil contaminants. This research evaluated the interaction of facultative bacteria Shewanella Oneidensis $M R-1$ with autunite mineral in bicarbonateamended media solutions. The concentration of several elements such as $\mathrm{U}$, calcium (Ca) and phosphorous $(\mathrm{P})$ released as a result of autunite mineral biodissolution were determined as a function of time; changes in cell density and protein assay were performed to evaluate cells viability. Results suggested that higher bicarbonate concentrations increased aqueous $\mathrm{U}, \mathrm{Ca}$ and $\mathrm{P}$ concentrations while also allowing cells to withstand $\mathrm{U}$ toxicity and, additionally suggested the possibility of secondary minerals formation. This research provides a better understanding on the stability of uranyl phosphate minerals in the presence of facultative bacteria in bicarbonate-amended media solutions. 


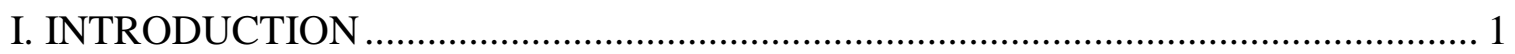

II. BACKGROUND ......................................................................................... 2

Hanford Site 300 Area.................................................................................... 2

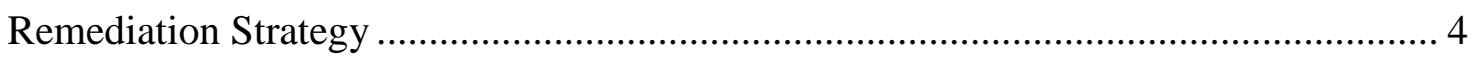

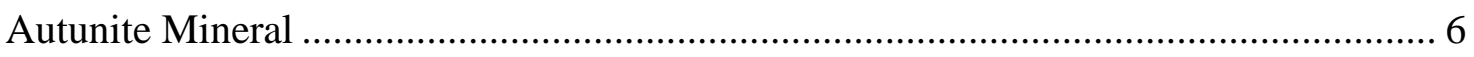

Facultative Anaerobic Bacteria ............................................................................ 7

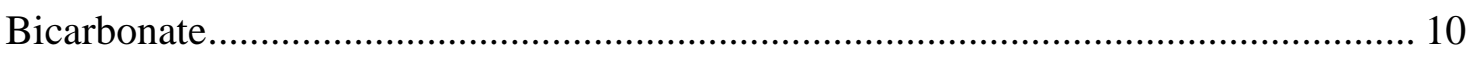

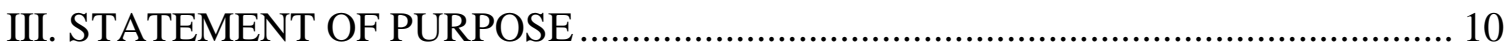

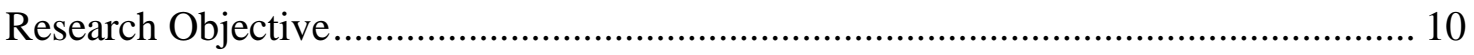

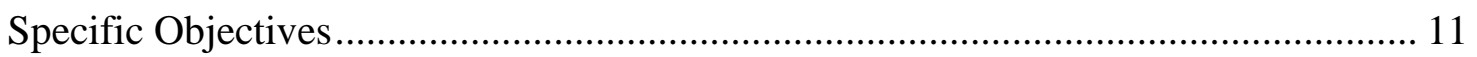

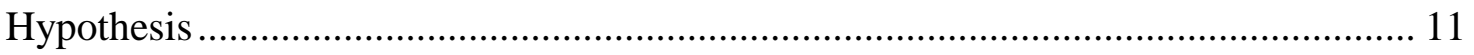

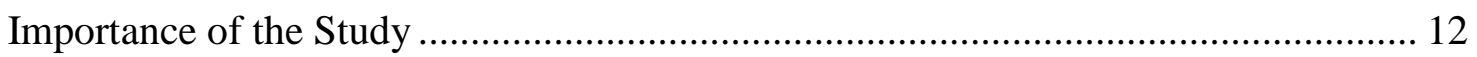

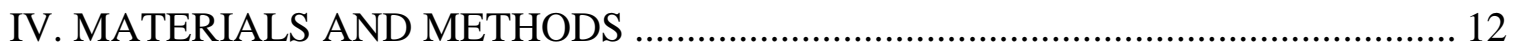

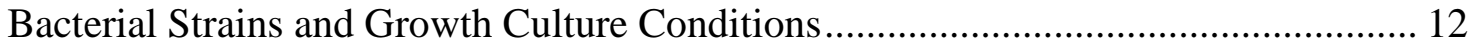

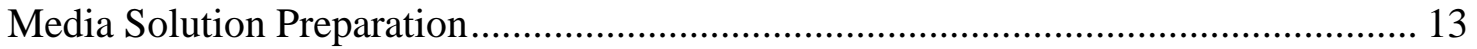

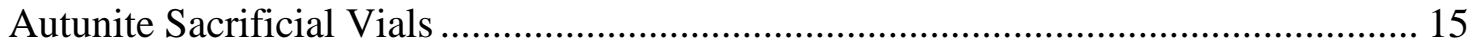

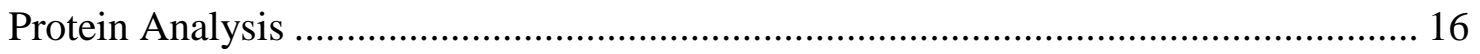

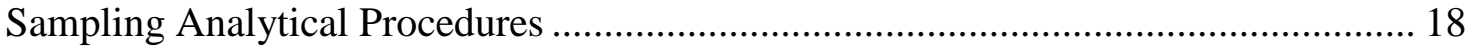

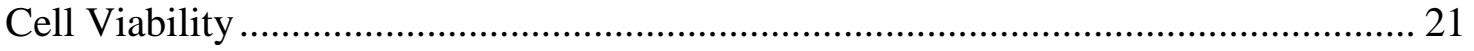

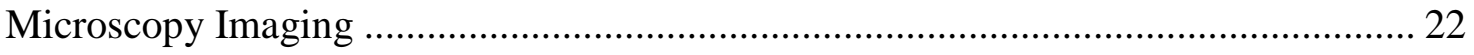

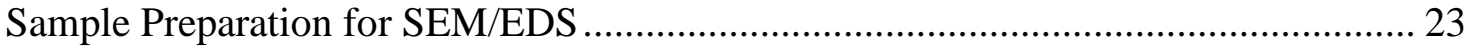

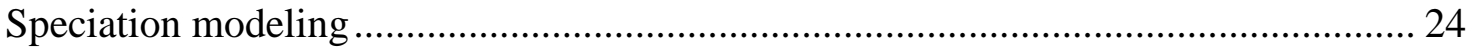

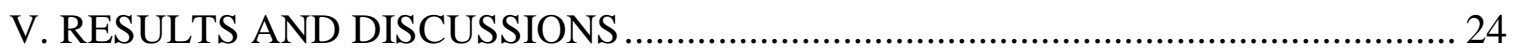

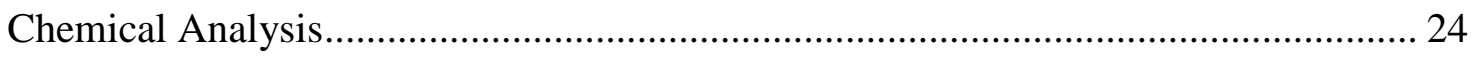

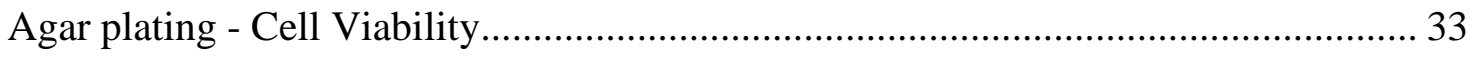

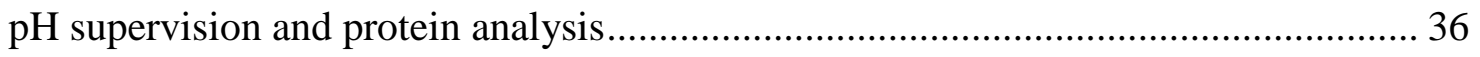

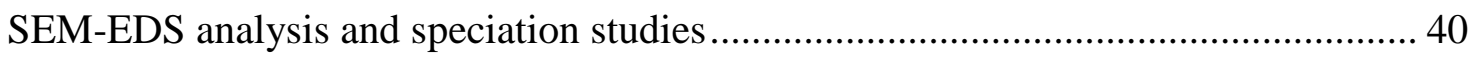


VI. CONCLUSIONS

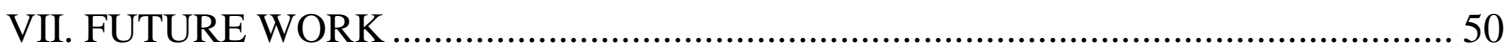

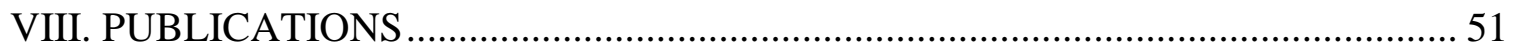

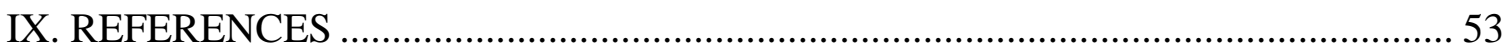




\section{LIST OF TABLES}

TABLE

PAGE

Table 1. Organization and labels used in the experiment for sacrificial vials in the

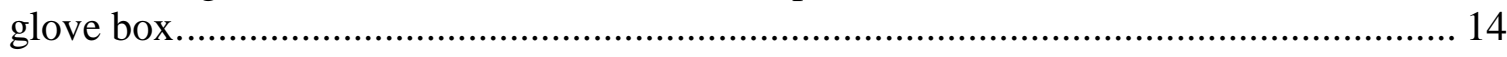

Table 2. Information about uses of experimental solution of each sacrificial vial........... 22

Table 3. Elemental analysis and energy distribution of sample shown on figure $29 \ldots . . . .41$

Table 4. EDS analysis over secondary minerals on shown on Figure 34....................... 45

Table 5. Soluble and Saturated Species for All Three Conditions Studied (bicarbonate-free samples and samples amended with 3 and $10 \mathrm{mM}$ bicarbonate) ......... 46 


\section{LIST OF FIGURES}

FIGURES

PAGE

Figure 1. Map of Hanford Site................................................................................ 5

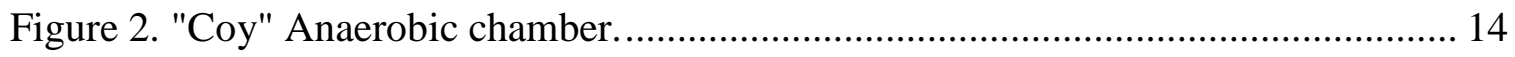

Figure 3. Sampling schedule before and after inoculation. .......................................... 15

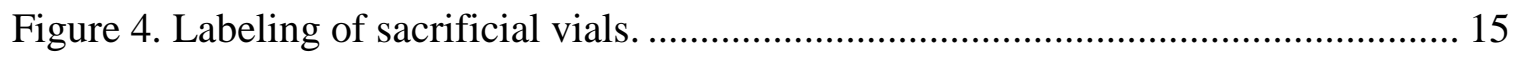

Figure 5. 20-mL glass scintillation vial prepared with media amended with $\mathrm{KHCO}_{3}$

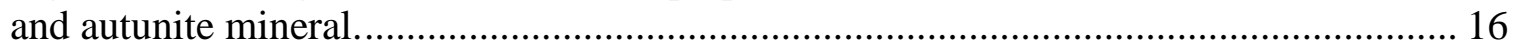

Figure 6. $15 \mathrm{~mL}$ plastic tube containing fresh culture. ............................................ 17

Figure 7. Water bath used for cell lysing following protein analysis. ........................... 18

Figure 8. Sacrificial vials inside the anaerobic chamber through sampling period.......... 19

Figure 9. Agar plates after calculating CFU........................................................ 21

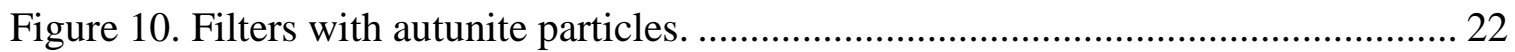

Figure 11. Uranium concentration as a function of time for bicarbonate-free samples. .. 25

Figure 12. Uranium concentration as a function of time for samples amended with

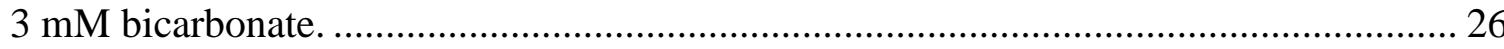

Figure 13. Figure 6. Uranium concentration as a function of time for samples amended with $10 \mathrm{mM}$ bicarbonate........................................................................ 27

Figure 14. Uranium concentration in the aqueous phase in the presence of Shewanella Oneidensis as a function of time, for three different bicarbonate conditions.28

Figure 15. Calcium concentration as a function of time for bicarbonate-free samples. Red points represent biotic samples while blue points represent abiotic samples............ 29

Figure 16. Calcium concentration as a function of time for samples amended with $3 \mathrm{mM}$ bicarbonate. Red points represent biotic samples while blue points represent abiotic samples. 
Figure 17. Calcium concentration as a function of time for samples amended with $10 \mathrm{mM}$ bicarbonate. Red points represent biotic samples while blue points represent abiotic samples.

Figure 19. Phosphorous concentration as a function of time for samples amended with $3 \mathrm{mM}$ bicarbonate. Red points represent biotic samples while blue points represent abiotic samples.

Figure 20. Phosphorous concentration as a function of time for samples amended with $10 \mathrm{mM}$ bicarbonate. Red points represent biotic samples while blue points represent abiotic samples.

Figure 21. Changes in the direct cell counts for samples containing varying concentrations of bicarbonate. 33

Figure 22. Results for the total cell density to viable cells for $0 \mathrm{mM} \mathrm{HCO}_{3}{ }^{-} \ldots \ldots \ldots \ldots \ldots . . . . . . .34$

Figure 23. Results for the total cell density to viable cells for $3 \mathrm{mM} \mathrm{HCO}_{3}{ }^{-} \ldots \ldots \ldots \ldots \ldots . . . . . . .35$

Figure 24. Results for the total cell density to viable cells for $10 \mathrm{mM} \mathrm{HCO}_{3}{ }^{-}$................. 35

Figure 25. pH of autunite suspensions as a function of time. Red lines represent biotic samples and blue lines abiotic samples.

Figure 26. Protein concentration as a function of time for Shewanella oneidensis grown under anaerobic conditions.

Figure 27. Correlation between cell density of Shewanella oneidensis MR-1 and protein content.

Figure 28. The variation of cell density (logarithmic scale) as function of time.

Figure 29. SEM image revealing structural damage of autunite and associated elemental composition by EDS analysis.

Figure 30. SEM image from autunite mineral related to a bicarbonate free sample. ....... 42

Figure 31. Bacterial activity on the surface of autunite ............................................. 42

Figure 32. Observed bacteria cells on autunite in $10 \mathrm{mM} \mathrm{HCO}_{3}{ }^{-}$media....................... 43

Figure 33. Secondary minerals observed on the surface of autunite. 
Figure 34. Secondary minerals with EDS analysis................................................. 45 


\section{INTRODUCTION}

Uranium is a key contaminant of concern at many U.S. Department of Energy (DOE) sites, such as the Hanford site that served in the nation's defense for over 50 years. Uranium contamination of soil and groundwater is of great environmental concern due to the toxicological properties of the uranyl species. The Columbia River is adjacent to the Hanford Site 300 Area and large scale remediation efforts have been done to treat uranium wastes released to soil and groundwater to prevent the movement of contaminated plumes into the river that serves as the main source of water supply for nearby populations. The water table at the 300 Area is very dynamic due to fluctuations in the stage of the Columbia River and Hanford formation sediments that comprise the uppermost part of the unconfined aquifer that has a very high permeability . The dynamics of river-stage fluctuations and the water-table elevation created a mixing zone of river and groundwater within the aquifer (Peterson and Rockhold M.L. 2008).

The behavior of uranium and its mobility in the subsurface are affected by various factors such as the chemistry of porewater, groundwater and soil minerals, as well as the presence of complex-forming ligands and microorganisms that thrive under these conditions.

Remediation techniques were applied at the Hanford 300 Area by injecting tripolyphosphate solutions into uranium bearing saturated porous media to immobilize uranium in groundwater by forming an insoluble mineral well known as autunite. Autunite minerals are uranyl phosphate solids that are rich in phosphorus, which is a nutrient for common microorganisms present in the soil. Recent investigations studied the interactions of aerobic microbes on the stability of uranyl phosphates minerals and their effects on the 
dissolution of autunite minerals (Carvajal 2011, Sepulveda-Medina 2014). This research is a continuation of the previous investigations focusing on the effects of facultative bacteria on the release of uranium from autunite minerals in bicarbonate-amended solutions. The interactions of facultative anaerobic bacteria with autunite solids can cause the destruction of the mineral while searching to satisfy their nutrients requirements; hence, causing migration of uranium back into the soluble phase.

\section{BACKGROUND}

\section{Hanford Site 300 Area}

Hanford site's 300 Area belongs to The Department of Energy (DOE) and is located adjacent to the Columbia River in Washington St. a few miles away from Richland city. During the Cold War, this site was involved in plutonium production for atomic weapons. The processing of raw uranium into fuel elements for nuclear reactors, and the reprocessing of irradiated fuel to obtain plutonium and other useful radioisotopes, has resulted in a wide variety of hazardous waste streams that contain chemical and radiological constituents. Tons of solid waste and thousands of gallons of liquid waste were also generated during time of plutonium production. These liquid wastes were disposed of by pouring onto the ground or into trenches or holding ponds. Unintentional spills of liquids also took place. Liquid wastes generated during the process of extracting plutonium from the uranium "fuel rods" were put into underground storage tanks. There are 149 underground single shell tanks (SST) used to store radioactive mixed waste; 67 of these SST's have been classified as assumed/confirmed leakers, which have leaked contaminants into the surrounding soil. The liquid waste leakage resulting from tank failure has soaked into the ground at the site 
and has created multiple radionuclide plumes, which are being monitored and treated to remove contaminants (Sepulveda-Medina 2014). The Hanford site represents two-thirds of the nation's high-level radioactivity by volume.

Now Hanford Site is facing challenging cleanup efforts including decommissioning, deactivation, decontamination and demolishing facilities built in the 1940's for storage of radioactive materials. Aqueous uranium denoted as $\mathrm{U}(\mathrm{VI})$ is a key contaminant of concern at the Hanford Site soil and groundwater; however, despite extensive remediation efforts initiated in the early 1990s, uranium groundwater plumes identified in multiple locations around the site have persisted for many years (DOE and EPA 2013). Groundwater beneath the 300 Area contains uranium from past practice disposal activities at concentrations that exceed the U.S. Environmental Protection Agency (EPA) standards for drinking water supplies. A joint effort between the Washington State Department of Health and Pacific Northwest National Laboratory, has been made with the objective to "identify any contamination present and determine if it could present a risk to humans, and to plant and animal life” (Peterson, Rockhold et al. 2008).

The Columbia River at the site exhibits water table fluctuations, which can vary up to $3 \mathrm{~m}$ seasonally. The thickness of the vadose zone varies as the water table moves up and down in response to changes in the Columbia River stage. A series of confined aquifers are found within the Columbia River Basalts that underlie the 300 Area sediments. The depth below ground surface to the top of the unconfined aquifer varies from a maximum of approximately $18 \mathrm{~m}$ to $0 \mathrm{~m}$ at the edge of the Columbia River. The water table elevation in the 300 Area varies with changes in Columbia River stage (Peterson, Rockhold et al. 2008) 
is rising water table over the extent of its annual vertical excursion creates an oxic-anoxic interface that in turn can affect the stability of uranium bearing solids created in soil sediments due to activities of facultative anaerobic bacteria in their search for nutrients.

Previous assessments noted the decline in cultivable aerobic bacteria in subsurface sediments and suggested the presence of facultative anaerobic bacteria in sediment samples collected from the impacted area (Lin, Kennedy et al. 2012).Therefore, understanding the role of anaerobic bacteria as one of the factors affecting the outcome of environmental remediation is very important.

\section{Remediation Strategy}

Uranium in its soluble form, $\mathrm{U}(\mathrm{VI})$, is of concern due to its chemical toxicity and risk for radiological exposure, even though the concentrations in groundwater for chemical toxicity are lower than those associated with exceeding radiological dose standards (Peterson, Rockhold et al. 2008). Despite the cessation of uranium releases and the removal of shallow vadose zone "hot" source materials, the remedial action objective to lower the concentration of groundwater uranium to the EPA maximum contaminant level (MCL) concentration for drinking water of $30 \mu \mathrm{g} / \mathrm{L}$ has not been achieved (Wellman, Pierce et al. 2009). Since the early 1990's, extensive remediation of liquid waste disposal sites and solid waste burial grounds have taken place. 


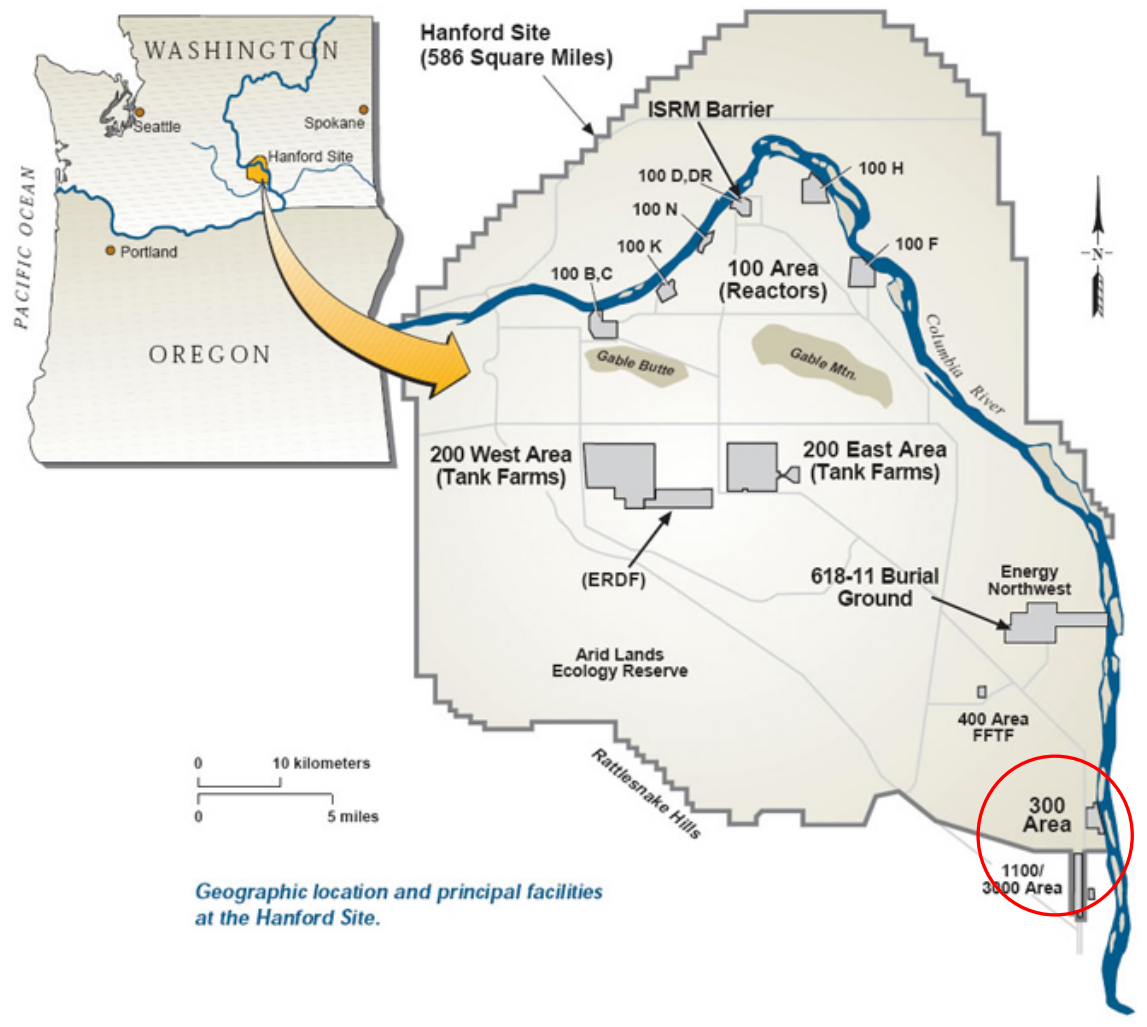

Figure 1. Map of Hanford Site.

Detailed analyses have previously indicated that uranium occurs as U(VI) through the 300 Area North Process Pond depth profile (Figure 1). Micro-scale X-ray spectroscopy identified uranium-rich calcite, uranophane, $\mathrm{Ca}\left(\mathrm{UO}_{2}\right)_{2}\left[\mathrm{SiO}_{3}(\mathrm{OH})\right]_{2} \cdot \mathrm{xH}_{2} \mathrm{O}$ and metatorbernite, $\mathrm{Cu}\left(\mathrm{UO}_{2}\right)_{2}\left(\mathrm{PO}_{4}\right)_{2} \cdot \mathrm{xH}_{2} \mathrm{O}$ (Catalano, McKinley et al. 2006), as uranium-bearing solid phases (Wellman, Pierce et al. 2009).

In an attempt to decrease the traces of $\mathrm{U}(\mathrm{VI})$ detected in contaminated plumes of the 300 Area, tripolyphosphate injections were performed as a remediation strategy. Long- chain sodium polyphosphate compounds $\left(\mathrm{Na}_{5} \mathrm{P}_{3} \mathrm{O}_{10} \cdot \mathrm{nH}_{2} \mathrm{O}\right)$ have been proposed as a time released source of phosphate for precipitation of uranium-phosphate minerals. Experiments 
on soluble polyphosphate compounds have been demonstrated to serve as an effective source of orthophosphate for controlled precipitation of phosphate phases to control the long term fate of uranium (Wellman, Gunderson et al. 2007).

The injection of sodium tripolyphosphate into uranium bearing porous media creates uranyl phosphate minerals such as autunite, $\left\{\left(\mathrm{X}^{\mathrm{m}}\right)_{2 / \mathrm{m}}\left[\left(\mathrm{UO}_{2}\right)(\mathrm{PO} 4)\right]_{2} \bullet \mathrm{xH}_{2} \mathrm{O}\right\}$, where $\mathrm{x}$ is a monovalent or divalent metal. (Finch and Murakami 1999) showed that in artificial autunites sodium can be replaced by calcium and the exchange reactions take place rapidly in Ca-rich environment with compounds of the autunite type creating hydrated calcium uranyl phosphate with formula $\mathrm{Ca}\left(\mathrm{UO}_{2}\right)_{2}\left(\mathrm{PO}_{4}\right) \cdot 10-12 \mathrm{H}_{2} \mathrm{O}$. Because autunite sequesters uranium in the oxidized form, $\mathrm{U}(\mathrm{VI})$, rather than forcing reduction to its insoluble form, U(IV), the possibility of re-oxidation of uranium is limited. Release of uranium from autunite may only occur through dissolution of the mineral structure. The stability of uranyl phosphate minerals in the subsurface is a critical factor, affecting the long term effectiveness of the implemented remediation technique.

\section{Autunite Mineral}

The bioreductive precipitation of $\mathrm{U}(\mathrm{VI})$ into sparingly insoluble uraninite, $\mathrm{UO}_{2+\mathrm{x}}$, is widely suggested as a potential in situ remediation tool to immobilize uranium. Recently, uranyl phosphate precipitation has also been suggested as a uranium remediation strategy (Smeaton, Weisener et al. 2008). Uranyl phosphates constitute the most diverse group of uranyl minerals with nearly 70 species identified (Finch and Murakami 1999).

In aqueous solutions, uranium forms strong complexes with oxygen containing ligands, phosphate being one of the most stable, even though concentrations of phosphate in pore 
fluids are typically low. Because of the strong affinity of uranium for phosphorus, autunite group mineralshave been identified as the long term controlling phase limiting the mobility of the uranyl cation $\left(\mathrm{UO}_{2}{ }^{2+}\right)$ in subsurface environments.

\section{Facultative Anaerobic Bacteria}

The mobility of uranium is impacted by local and regional redox transformations between insoluble $\mathrm{U}(\mathrm{IV})$ and soluble $\mathrm{U}(\mathrm{VI})$ species, sorption, and aqueous complexation. In the subsurface, bacteria and other microorganisms can dramatically impact the speciation and distribution of uranium in near surface geologic settings through non-metabolic and metabolic processes.

Many environmental systems have microbial activities and can influence U(VI) mobilization. In nature, a variety of bacteria may enhance the mobility of heavy metals or radionuclides by dissolution and desorption reactions due to the secretion of protons and various ligands (Carvajal, Katsenovich et al. 2012).

Because autunite contains phosphorous as part of the mineral structure, it can attract bacteria that are in search for vital nutrients to maintain metabolic functions. Microbial activities can affect the stability $\mathrm{U}(\mathrm{VI})$ bearing minerals in search for their nutritional requirements causing a breakdown of the autunite mineral; thus, liberating uranium into soluble phase. Microbes have different characteristics that lead them to survive under extreme environments. Despite the environmental relevance, few studies exist on the biotic dissolution of the solid uranyl mineral phases (Sepulveda-Medina 2014). This is the case of aerobic microorganism, Arthrobacter oxydans, used in the present study. Shewanella Oneidensis MR-1 strain was obtained from Pacific Northwest National Laboratory 
(PNNL). This strain is a gram negative proteobacteria that have typically rod shape, with dimensions ranging between 2-3 $\mu \mathrm{m}$ in length and 0.4-0.7 $\mu \mathrm{m}$ in diameter. It is a common bacterial group found in Hanford soils (Bernhard, Geipel et al. 2001, Brooks, Fredrickson et al. 2003), pertains to the facultative anaerobic species and due to their ability to reduce metals as a part of their metabolic pathway, it also belongs to a group known as dissimilatory metal-reducing bacteria (DMRB). The ability to respire on insoluble substances allows them to thrive under extreme conditions, without oxygen and in a toxic environment. The mechanism of action for metal reduction is by a biofilm formation. Therefore, the first step to successful reduction of extracellular metals is the formation of biofilms on the metal oxide. Biofilms facilitate close contact between the bacteria and the oxidized metal (Wu, Cheng et al. 2013). A study by (Thormann, Saville et al. 2004) investigated the mechanism of biofilm formation by Shewanella Oneidensis MR-1 on glass surfaces. They reported that the microbes first attach and then grow laterally until they cover the entire surface available to them.

Previously, a few studies looked at the effect of a dissimilatory metal-reducing bacterium (DMRB), Shewanella Putrefaciens 200R and Shewanella Oneidensis MR-1 (Sheng and Fein 2013, Sheng and Fein 2014) on the microbial dissolution of autunite in the anaerobic conditions (Smeaton, Weisener et al. 2008). Recent experiments with aerobic Arthrobacter Oxydans strains illustrated a bio-enhanced release of U(VI) from natural Ca-autunite in the presence of various concentrations of bicarbonate. Arthrobacter strains, Arthrobacter Oxydans G968 and G975, that exhibited various degrees of tolerance to U(VI) toxicity, were able to bio-enhance the release of $\mathrm{U}(\mathrm{VI})$ from natural Ca-autunite at almost the same 
capacity (Katsenovich, Carvajal et al. 2013). Other recent investigations (BencheikhLatmani and Leckie 2003, Katsenovich, Carvajal et al. 2012) have also suggested that uranyl-carbonate complexes formed in the solution do not strongly interact with the negatively charged bacterial surface, which in turn can mitigate U(VI) toxicity on cells.

Previous studies examined the effects of temperature, $\mathrm{pH}$ and dissolved organic matter on Na-autunite and Ca-autunuite and showed that the dissolution of minerals depends on $\mathrm{pH}$ and the concentration of dissolved organic material(Wellman, Icenhower et al. 2006). Results suggested that aqueous uranium release is affected by $\mathrm{pH}$ but in the case of phosphorous the release rates remained unaffected. This finding supports the hypothesis that the dissolution of autunite group minerals is controlled by a surface-mediated reaction with the U-O polyhedral (Gudavalli, Katsenovich et al. 2013).

Microbial cell walls have complex properties and some of their reactions are controlled by ion exchange as part of non-metabolic processes that involve physical and chemical interactions. Metabolic dependent processes involve the formation of chelating agents, enzymatic uranium reduction and precipitation (Suzuki and Banfield 1999). Previous research identified uranium in precipitated autunite mineral phases on the bacterial surface. DMRB generate energy for growth by coupling the oxidation of an organic carbon source (i.e., lactate, glucose, etc.) to the reduction of a terminal electron acceptor (TEA) (i.e., uranyl cation) (Anderson and Lovley 2002; Suzuki and Banfield 1999). Speciation modeling suggests the formation of highly stable, neutral and negatively charged uranylcarbonate and calcium uranyl-carbonate complexes; among them neutral species are able to adsorb onto the bacterial surface, leading to significantly enhanced adsorption in the $\mathrm{pH}$ 
range 7-9(Roberts , Fowle et al. 2006). The adsorption of these negatively charged complexes have not been expected since the bacterial surface was negatively charged as well (Dunham-Cheatham, 2014 \#38).

\section{Bicarbonate}

Uranium exists in four oxidation states but, under oxidizing conditions, it dominates as a highly soluble and stable uranyl ion, $\mathrm{UO}_{2}{ }^{2+}$. In neutral or basic $\mathrm{pH}$ conditions, uranium undergoes hydrolysis in aqueous solutions and can readily complex with a wide variety of ligands such as carbonate, nitrate and phosphate. In a bicarbonate rich environment, carbonate anions are an important complexing agent for $\mathrm{U}(\mathrm{VI})$, leading to the formation of negatively charged soluble uranyl-carbonate complexes such as $\mathrm{UO}_{2}\left(\mathrm{CO}_{3}\right)_{2}{ }^{2-}$ and $\mathrm{UO}_{2}\left(\mathrm{CO}_{3}\right)_{3}{ }^{4-}$, as well as neutral complexes such as $\mathrm{UO}_{2} \mathrm{CO}_{3}{ }^{0}$ (Bachmaf, Planer-Friedrich et al. 2008). The presence of carbonates in the aqueous phase facilitates uranium desorption from soil and sediments and promotes the release of $\mathrm{U}(\mathrm{VI})$ into the aqueous phase; thus, increasing uranium mobility in natural waters (Langmuir 1978). Uranyl-bicarbonate complexes have been identified in contaminated pore water and groundwater at the Hanford Site, Washington St. (Bernhard, Geipel et al. 2001, Brooks, Fredrickson et al. 2003).

\section{STATEMENT OF PURPOSE}

\section{Research Objective}

Autunite stability in the subsurface is a key factor affecting the long term effectiveness of the tripolyphosphate injection remediation strategy. The purpose of this investigation is to evaluate the effect of facultative bacteria, Shewanella Oneidensis $M R-1$, isolated from 
Hanford 300 Area soil on the dissolution of autunite mineral in the presence of bicarbonate anions. The study also investigates changes in $\mathrm{U}(\mathrm{VI}), \mathrm{Ca}$ and $\mathrm{P}$ concentrations in the aqueous solutions, changes in cells density and viability, and evaluates for post-reacted autunite solids via Scanning Electron Microscopy SEM/EDS.

\section{Specific Objectives}

The general objective of this study is to investigate the dissolution of uranyl-phosphate minerals by facultative bacteria in bicarbonate amended media. More specifically, the objectives are:

(i) Study the potential role of Shewanella Oneidensis $M R-1$ cells to affect the biorelease of Ca-autuniute solids in the presence of varying concentrations of bicarbonate.

(ii) Investigate changes in cell density and cell viability in the presence of varying concentrations of bicarbonate.

(iii) Conduct protein assays and evaluate bacterial cell morphology under the three bicarbonate concentrations tested using SEM/EDS analysis.

\section{Hypothesis}

\section{Experimental Hypothesis}

In the present study it is hypothesized that:

1. Media amended with bicarbonate will increase the release of uranium from Caautunite compared to bicarbonate- free media.

2. Presence of bicarbonate will reduce uranium toxicity. 
3. Release of uranium may affect the mineral structure and cause the release of Ca and $\mathrm{P}$. The release of $\mathrm{P}$ will be higher in biotic samples than in abiotic controls.

4. Uranium toxicity can affect bacterial viability and protein content.

\section{Importance of the Study}

Environmental remediation is of paramount importance to restore sites that have been heavily contaminated by nuclear waste. Uranium has been found to be one of the predominant pollutants of the Hanford area and represents a risk to the natural waters that are close to the site. Due to its toxicity, long half-life $\left(4.5 \times 10^{9}\right.$ years), and potential mobility in the environment, understanding the mechanisms of uranium migration from the DOE nuclear waste disposal sites is a vital task (Finch and Murakami 1999) in managing radioactive contaminants. In this research the role of microorganisms has been analyzed by studying the possible effects of an anaerobic facultative strain isolated from the Hanford Site 300 area on the biodissolution of minerals created in the remediation strategies applied to groundwater uranium contamination. The scope of the study is to replicate soil conditions from Hanford's 300 area by recreating conditions pertaining to the aquifers by using similar media solutions in the laboratory batch experiments. The results are expected to help understand the fate and risks associated with the long term remediation techniques applied to soil and groundwater.

\section{MATERIALS AND METHODS}

\section{Bacterial Strains and Growth Culture Conditions}

Shwanella Oneidensis MR-1 was prepared prior to inoculation of experimental vials by creating fresh culture for strains grown on sterile hard and liquid Luria-Bertani (LB) media 
made with $10.0 \mathrm{~g}$ of tryptone, $5.0 \mathrm{~g}$ of yeast extract, and $10.0 \mathrm{~g}$ of sodium chloride, with a $\mathrm{pH}$ of 7.0. Hard media required an addition of $15.0 \mathrm{~g}$ of agar. Then fresh culture was grown in $15 \mathrm{~mL}$ tubes placed in the incubator for two days at $30^{\circ} \mathrm{C}$. Bacterial cells were harvested in the late logarithmic phase of growth and cell density (cells/mL) was calculated with the use of a glass hemocytometer (Fisher Scientific, Pittsburgh, PA) to determine the concentration of a stock solution and estimate a desired volume $(\mathrm{mL})$ of a bacterial suspension needed for the inoculation of each bottle. In addition, fresh bacterial culture was preserved in $25 \%$ glycerol at the temperature of $-80^{\circ} \mathrm{C}$.

\section{Media Solution Preparation}

Aqueous carbonate ions present in the soil and ground water are the predominant aqueous species affecting the dissolution of uranium-bearing solids and facilitating uranium desorption reactions from soil and sediments, thus increasing uranium mobility in soil and sediments. The media solution to conduct the autunite dissolution experiments was prepared similar to the growth media without yeast extract due to its high phosphorus content by mixing $1 \mathrm{~L}$ of deionized water (DIW) (Barnstead NANOpure Diamond Life Science (UV/UF), Thermo Scientific), 0.02 M of Na-Hepes buffer with pH adjusted to 7.1 and $24 \mathrm{mM}$ of sodium lactate $\left(\mathrm{C}_{3} \mathrm{H}_{5} \mathrm{NaO}_{3}, 60 \% \mathrm{w} / \mathrm{w}\right)$. The resulting solution was equally distributed into three $500 \mathrm{~mL}$ flasks and sterilized by autoclaving for $15 \mathrm{~min}$ at $121^{\circ} \mathrm{C}$. After autoclaving, each flask was amended with potassium bicarbonate to 0,3 or $10 \mathrm{mM}$ bicarbonate respectively, and then sterile media solutions were filter sterilized into sterile $500 \mathrm{~mL}$ bottles. The bottles with the media solutions amended with bicarbonate were stored 
in a "Coy" anaerobic chamber to guarantee the removal of dissolved $\mathrm{O}_{2}$ until initiation of the experiment (

Figure 2). Labeling the vials appropriately was very important to avoid mistakes on sampling days; a table (Table 1) was prepared in the same order as the box containing the vials in the anaerobic chamber.

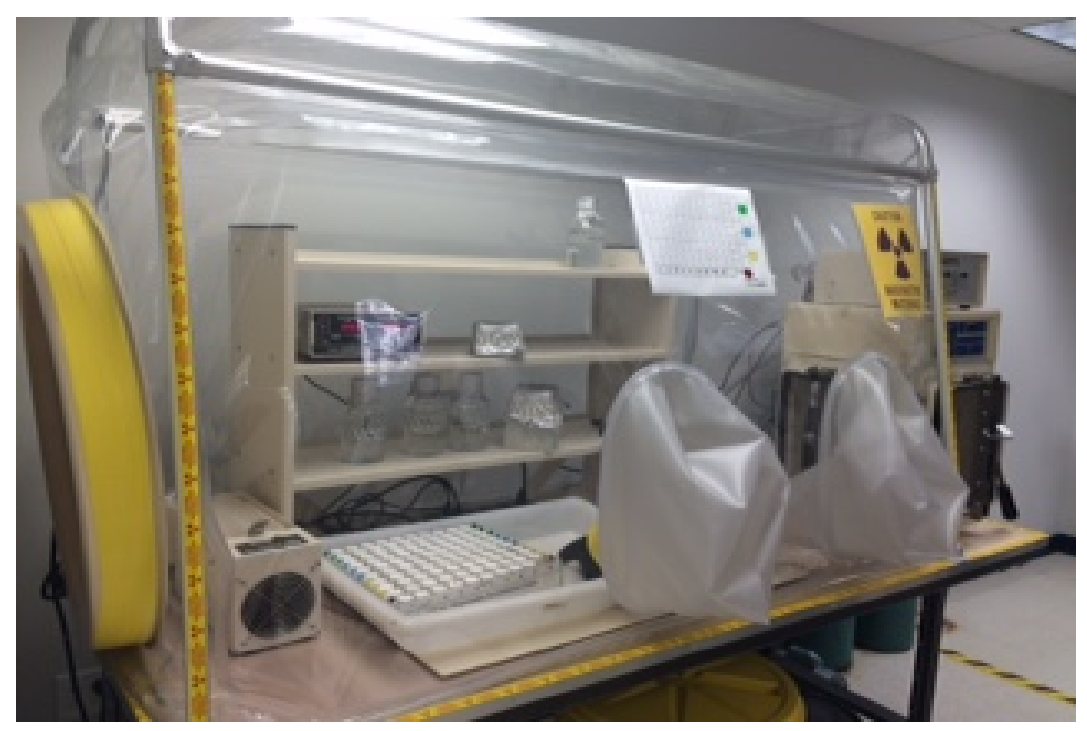

Figure 2. "Coy" Anaerobic chamber.

Table 1. Organization and labels used in the experiment for sacrificial vials in the glove box.

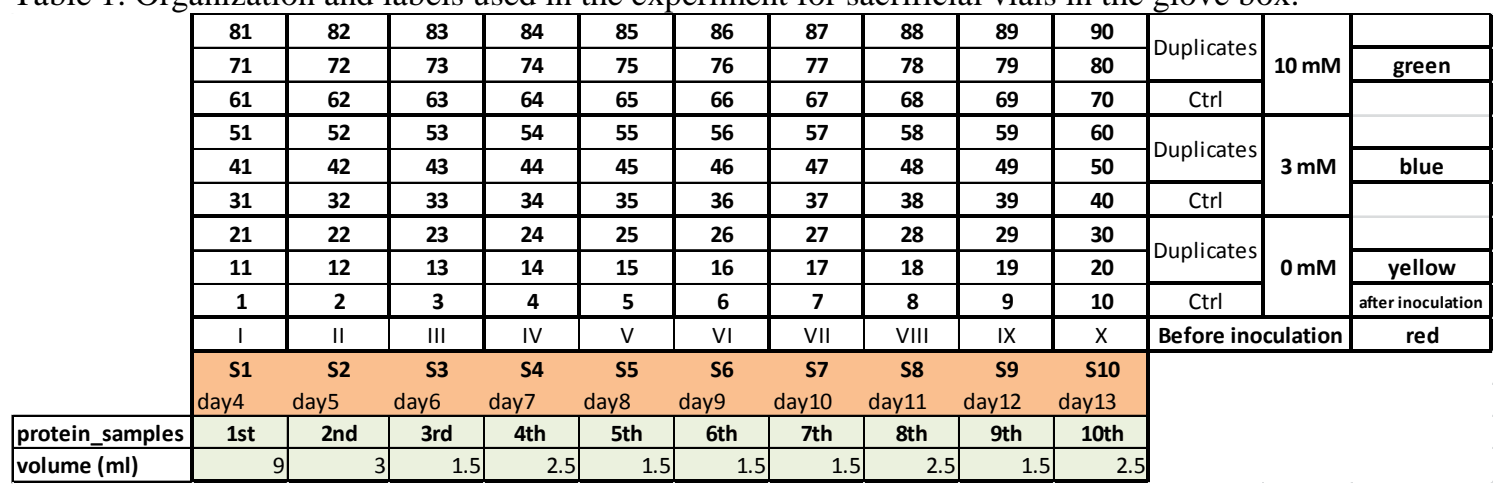




\section{Autunite Sacrificial Vials}

Experiment was conducted using sacrificial $20 \mathrm{~mL}$ glass scintillation vials. The total number of sacrificial vials for the duration of experiment was calculated as 99. Samples were sacrificed at specific time intervals according to the planned sampling schedule as shown in Figure 3. Set of duplicate biotic samples were inoculated with bacteria at day 10.

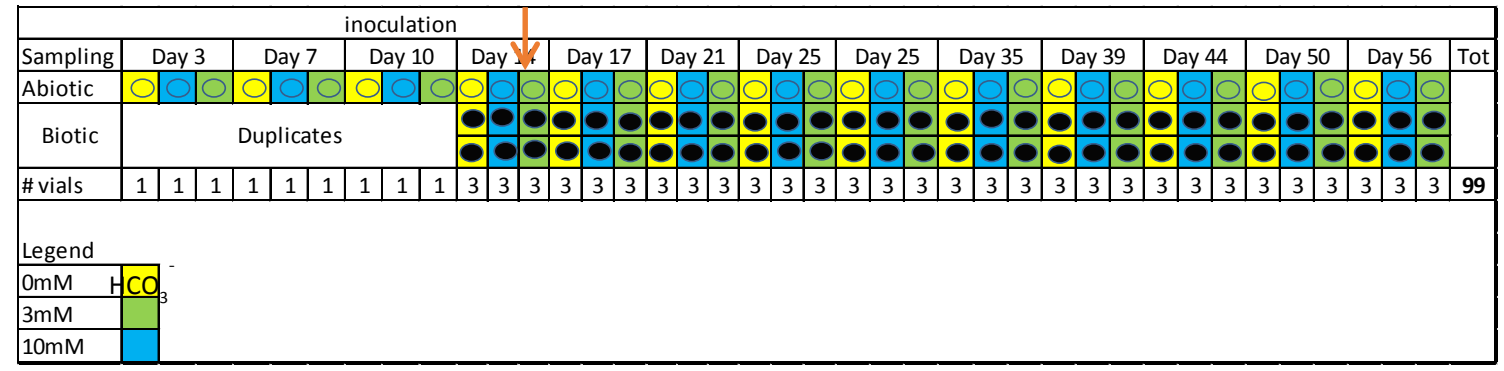

Figure 3. Sampling schedule before and after inoculation.

Each glass vial was filled with $18 \mathrm{mg}$ of powder autunite, covered with plastic caps and autoclaved for $15 \mathrm{~min}$ at $121^{\circ} \mathrm{C}$ to ensure sterile conditions. All of the glass vials were labeled to be easily differentiated (Figure 4) and placed into the glove box along with bottles having different bicarbonate media concentrations.

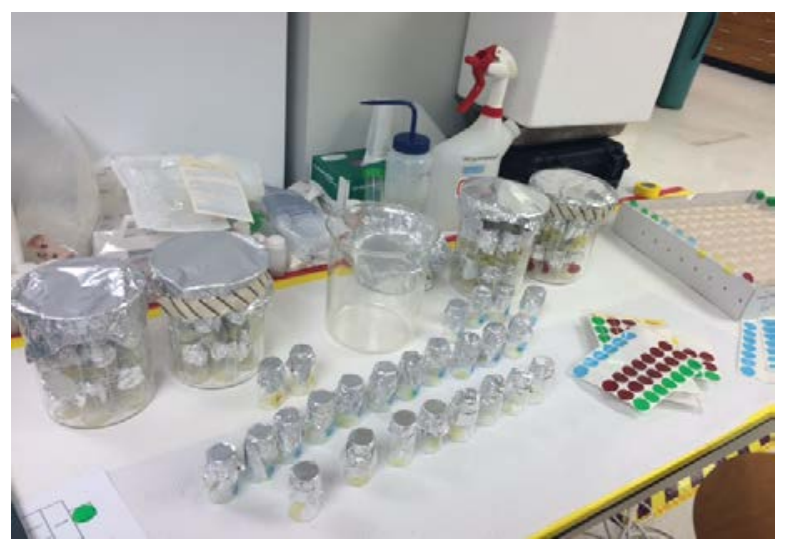

Figure 4. Labeling of sacrificial vials. 
Experimental vialas were kept in strictly anaerobic conditions. For that purpose all sacrificial vials were placed in the glove box and $10 \mathrm{~mL}$ of sterile media, that was previously amended with 0,3 , and $10 \mathrm{mM}$ of $\mathrm{KHCO}_{3}$, was added to each vial to provide a final U(VI) concentration of $4.4 \mathrm{mM}$ (Figure 5). This concentration was used to compare results with previous data obtained in the autunite mineral dissolution experiments using Arthrobacter oxydans strains, G968 and G975 (Sepulveda-Medina 2014) and in the research conducted by Liu et al. on the dissolution of Na-boltwoodite in anaerobic conditions by Shewanella Oneidensis strain MR-1 (Katsenovich, Carvajal et al. 2012).

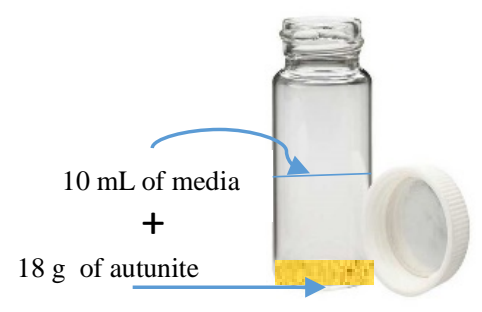

Figure 5. 20-mL glass scintillation vial prepared with media amended with $\mathrm{KHCO}_{3}$ and autunite mineral.

\section{Protein Analysis}

Cell protein determination was prepared according to Bicinchoninic Acid (BCA) (Pierce) bacterial cells protein analysis to obtain the cell density used for experimental inoculation with bacteria. With the aid of protein standards and known bacterial suspensions, the protein content is correlated to the number of cells, and by this way bacterial growth is monitored in the presence of different uranium and bicarbonate concentrations.

For protein analysis, a fresh culture of facultative bacteria Shewanella Oneidensis MR-1 was grown in two $15 \mathrm{~mL}$ tubes filled with LB liquid media (Figure 6). The tubes were placed into the incubator for two days at $30^{\circ} \mathrm{C}$. After two days the average concentration 
of stock solution calculated using a hemocytometer from the two cultures grown in the fresh culture tubes was around $3.12 \times 10^{8}$ cells $/ \mathrm{mL}$. The estimated volume of a bacterial suspension needed for the inoculation of each biotic sample was $32.1 \mu \mathrm{L}$ to obtain $10^{6}$ cells/mL.

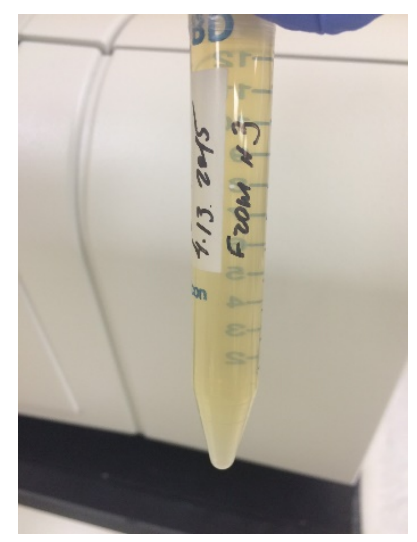

Figure 6. $15 \mathrm{~mL}$ plastic tube containing fresh culture.

After counting of cells, fresh culture from the tubes was centrifuged and the pellet was washed with DIW water and re-suspended in $1.5 \mathrm{~mL}$ of DIW water. The washing procedures were repeated twice. After washing, the cells were counted again via hemocytometer and $1.2 \mathrm{~mL}$ from each vial was extracted into the $1.5 \mathrm{~mL}$ microcentrifuge tubes to be used for the Bicinchoninic Acid (BCA) protein assay. The BCA Protein Assay combines the reduction of $\mathrm{Cu}^{2+}$ to $\mathrm{Cu}^{+}$by protein in an alkaline medium with the highly sensitive and selective colorimetric detection of the cuprous cation $\left(\mathrm{Cu}^{+}\right)$by bicinchoninic acid. Working reagents (WR) included in the BCA protein assay kit were prepared by mixing 50 parts of solution 1 and 1 part of solution B. The WR solution was used to build a calibration curve using albumin as a standard. Following the protocol procedures, the cells were lysed by boiling at $100^{\circ} \mathrm{C}$ (Figure 7) for $10 \mathrm{~min}$ and then cooled on ice. The 
lysate in different dilutions was used for the protein analysis and values were correlated with the cell densities prepared at specific dilutions.

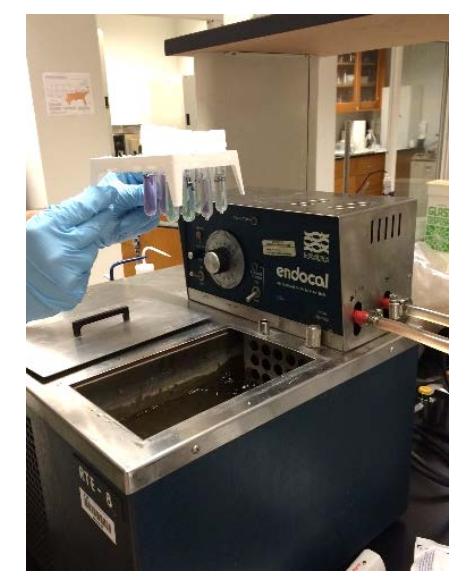

Figure 7. Water bath used for cell lysing following protein analysis.

\section{Sampling Analytical Procedures}

To allow the media solutions to equilibrate with the autunite mineral in the media solution, three abiotic samples were prepared at each bicarbonate concentration and samples were taken every 5 days before bacteria inoculation. The interval of time between sampling events after the media equilibrated with the autunite and bacteria inoculation was about 45 days (Figure 8). Every scheduled sampling event consisted on selecting from the anaerobic chamber a duplicate set of vials inoculated with bacteria and a third abiotic vial used as a control for each bicarbonate concentration (0, 3 and $\left.10 \mathrm{mM} \mathrm{HCO}_{3}{ }^{-}\right)$. The final number of vials used on every sampling day, after inoculation with bacteria, was 9 . 


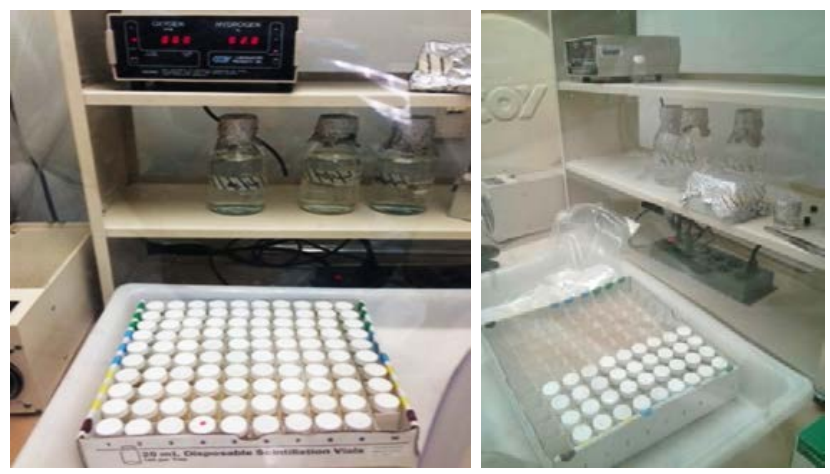

Figure 8. Sacrificial vials inside the anaerobic chamber through sampling period.

According to the time intervals determined by the experimental schedule, selected vials were taken out of the anaerobic chamber and sacrificed to collect aliquots of $1 \mathrm{~mL}$ from the supernatant of experimental solution by means of a sterile $1 \mathrm{~mL}$ syringe (BD) and filtered through $0.45 \mu \mathrm{m}$ PTFE filters into a $1.5 \mathrm{~mL}$ capacity (GC) brown vial. The filtrate was acidified with 1 drop of $1 \mathrm{M}$ of nitric acid $\left(\mathrm{HNO}_{3}{ }^{-}\right)$to preserve samples and kept at $4^{\circ} \mathrm{C}$ for chemical analysis to determine uranium concentrations released into the aqueous phase as a function of time by means of Kinetic Phosphorescence Analyzer KPA-11 (Chemcheck Instruments, Richland, WA). Uranium calibration standards (SPEX certiprep), blanks and check standards (95-105\% recovery) were analyzed for quality control before the experiment to check the variability of the instrument. In addition, aqueous concentrations of calcium and phosphorous were determined from digested samples using ashing procedures by means of inductively coupled plasma - optical emission spectroscopy (ICP-OES 7300 Optima, Perkin Elmer) using calcium and phosphorous standards (Spex Certi-Prep) for quality control.

The presence of organic content in the solutions can interfere with KPA measurements; hence, aliquots collected during the experiments were processed by ashing. Ashing in 
analytical chemistry is defined as the heating of a substance to leave only noncombustible ash, which is analyzed for its elemental composition. The ashing techniques are used widely only for samples containing a significant amount of combustible or organic material. In this research two ashing procedures were used, wet ashing followed by dry ashing procedures. A modified ashing technique described by (Ejnik, Hamilton et al. 2000) was used for wet and dry ashing when preparing the samples for chemical analysis.

KPA instrument is able to measure uranium concentrations within the range of $(0.1-100)$ $\mathrm{ppb}$, for that reason $0.2 \mathrm{~mL}$ of experimental solutions were taken from the brown vials into another $20 \mathrm{~mL}$ glass vials and were diluted for that purpose after ashing procedures. Wet ashing was performed by the addition of $0.5 \mathrm{~mL}$ of concentrated nitric acid $\left(\mathrm{HNO}_{3}{ }^{-}\right)$and $0.5 \mathrm{~mL}$ of concentrated hydrogen peroxide $\left(\mathrm{H}_{2} \mathrm{O}_{2}\right)$ to each $20 \mathrm{~mL}$ vial containing $0.2 \mathrm{~mL}$ of experimental solution; the vials were placed on a heating plate until full evaporation was achieved and a white solid residue was acquired. Occasionally, some samples turned yellow while ashing; $0.5 \mathrm{~mL}$ of peroxide was added to these samples and the process of heating was continued until a white precipitate was obtained. Dry ashing was performed when the dry samples were placed in a furnace preheated to $450^{\circ} \mathrm{C}$ for 15 min and then allowed to cool at room temperature. Finally, precipitates obtained in the drying step were dissolved in $1 \mathrm{~mL}$ of $2 \mathrm{M}\left(\mathrm{HNO}_{3}{ }^{-}\right)$and specific dilutions factors of 50 for the low bicarbonate concentration ( $\left.3 \mathrm{mM} \mathrm{KHCO}_{3}\right)$ and 200 for the high concentration $(10 \mathrm{mM}$ $\mathrm{KHCO}_{3}$ ) where applied for preceding analyses by means of the KPA and ICP-OES. 


\section{Cell Viability}

To account for viable bacteria, a well-mixed homogeneous aliquot of $0.02 \mathrm{~mL}$ of the suspension from each biotic sample subsequently diluted 1:10, 1:100 and 1:1000 was uniformly spreaded on sterile LB-agar Petri Dish plates containing LB growth media prepared with agar. The inoculated plates were kept inverted in an incubator at $30^{\circ} \mathrm{C}$. Viable microorganisms were calculated from the number of colony-forming units (CFU) found on a specific dilution (Figure 9). In addition, the agar plating was used to provide a quick visual check for contamination.

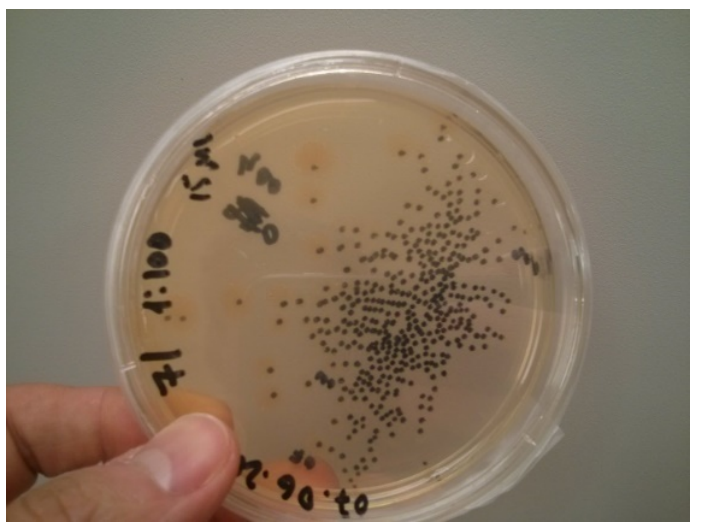

Figure 9. Agar plates after calculating CFU.

The remaining experimental solution (Table 2) in the sacrificed glass vial was used to measure $\mathrm{pH}$ and conductivity preceded with a vacuum filtration procedure by means of an $8 \mu \mathrm{m}$ filter in order to separate autunite particles that remain on the filter and bacteria, which pass to the filtrate (Figure 10). Filters containing autunite particles were stored at room temperature for further Scanning Electron Microscopy (SEM) analysis. 
Table 2. Information about uses of experimental solution of each sacrificial vial.

\begin{tabular}{|c|c|}
\hline Experimental solution & Volume \\
\hline Initial experiment & $10 \mathrm{~mL}$ \\
\hline $\begin{array}{c}\text { Distribution of } \\
\text { experimental solution }\end{array}$ & Volume \\
\hline Chemical analysis & $1 \mathrm{~mL}$ \\
\hline Agar plating & $0.02 \mathrm{~mL}$ \\
\hline Vacuum filtration & $8.98 \mathrm{~mL}$ \\
\hline
\end{tabular}

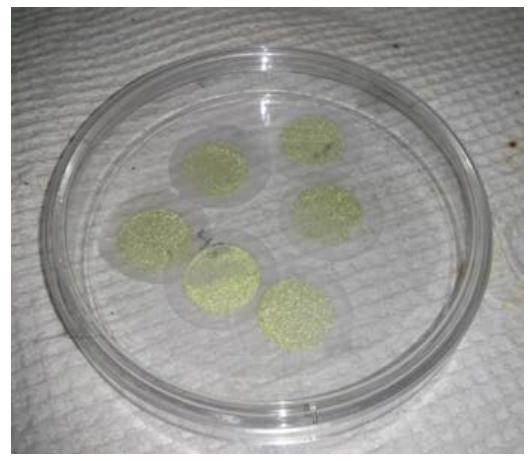

Figure 10. Filters with autunite particles.

The filtered solution was stored in a $15 \mathrm{~mL}$ plastic tube then divided in two parts: $2 \mathrm{~mL}$ was taken for protein analysis and the third part was diluted with 50\% glycerol in a ratio $1: 1$ and stored at $-80^{\circ} \mathrm{C}$.

\section{Microscopy Imaging}

Images are widely recognized tools for observation and analysis of samples in research studies. In this investigation a light microscope Meiji ML 2000 was used for nondestructive examination to quantify cells with the use of a disposable hemocytometer. A final evaluation of the morphology of the cells surface and mineral destruction was assessed by the SEM JOEL, JSM-630F instrument and EDS to determine the composition of the microbial surface. The purpose of SEM/EDS was to show surface morphology and cell surface composition in the presence of different bicarbonate concentrations. Interaction between microorganisms and mineral was expected by observing a biofilm formation as 
an evidence of attachment from bacteria to autunite surface as a mean to maintain metabolic exchange processes. Energy dispersive spectroscopy (EDS) analysis was performed to examine changes in mineral surface composition over time as a complimentary assessment to obtain more information about the elements characterization and their distribution on the observed samples.

\section{Sample Preparation for SEM/EDS}

Filtrates were centrifuged at a velocity $4000 \mathrm{rpm}$ for 5 minutes at a temperature of $18^{\circ} \mathrm{C}$ and supernatant was discarded. Obtained pellet was resuspended in a specific volume that was recorded of autoclaved DIW and cells were counted via hemocytometer having approximately 600,000 cells $/ \mathrm{mL}$ range in the log scale of 6 . The cells were fixed in $5 \mathrm{~mL}$ of $2 \%$ glutaraldehyde in $0.1 \mathrm{~mol} / \mathrm{L}$ HEPES buffer at $\mathrm{pH} 7.2$ for 2 hours at $4^{\circ} \mathrm{C}$. The material was removed and washed with $50 \mathrm{mM}$ HEPES buffer three times for 10 minutes. The rinsed cells were then dehydrated in ethanol water solutions of $35 \%(\mathrm{v} / \mathrm{v}), 70 \%(\mathrm{v} / \mathrm{v})$ and $90 \%$ (v/v) each for $10 \mathrm{~min}$, and two times in 100\% (v/v) for 10 minutes. Dehydrated samples were immersed for 10 more minutes, each in 50\% and 100\% pure hexamethyldisilazane (HDMS) (Pierce Biotechnology, Inc, obtained from Fisher Scientific) followed by 10 minutes of air-drying to allow liquid to evaporate from the sample. The dehydrated specimens were then kept in the desiccators until the moment of the SEM/EDS assay. On the day of the analysis dehydrated specimens related to higher concentration of bicarbonate were chosen and mounted on aluminum stabs that fits in SEM specimen holder with the help of double-sticky carbon tape and surveyed with rate meter before transporting them to the imaging laboratory. Prepared stabs went through a process of surface coating with a 
thin layer of gold for some samples while others with a layer of gold palladium for comparison purposes and overall to increase conductivity at the moment of making SEM observations.

\section{Speciation modeling}

Speciation modeling was used to predict different uranium species in the aqueous phase, as well as the formation of secondary minerals. The software that supported this study was Visual MINTEQ (v.3.0, maintained by J. Gustafsson at KTH, Sweden, available athttp://www.lwr.kth.se/English/OurSoftware/vminteq/ updated with the Nuclear Energy Agency's thermodynamic database for uranium) to identify the predominant uranium species in aqueous media solutions from the applied treatments. The model was run with the described concentrations of the aqueous SGW and amended with variated bicarbonate concentrations (0, 3 and $10 \mathrm{mM})$ as well as $\mathrm{pH}$ fixed at $6.96,7.25$ and 7.8 respectively. Autunite was an input set as a finite solid phase, since the mineral was in the form of powder. The experiment was not considered open air reason and the only gas input for the model was nitrogen at 1 atm.

\section{RESULTS AND DISCUSSIONS}

\section{Chemical Analysis}

The results of $\mathrm{U}(\mathrm{VI})$ concentration in the aqueous phase as function of time for each condition studied $\left(0,3\right.$ and $\left.10 \mathrm{mM} \mathrm{HCO}_{3}{ }^{-}\right)$are presented in Figures 11, 12 and 13 respectively. 


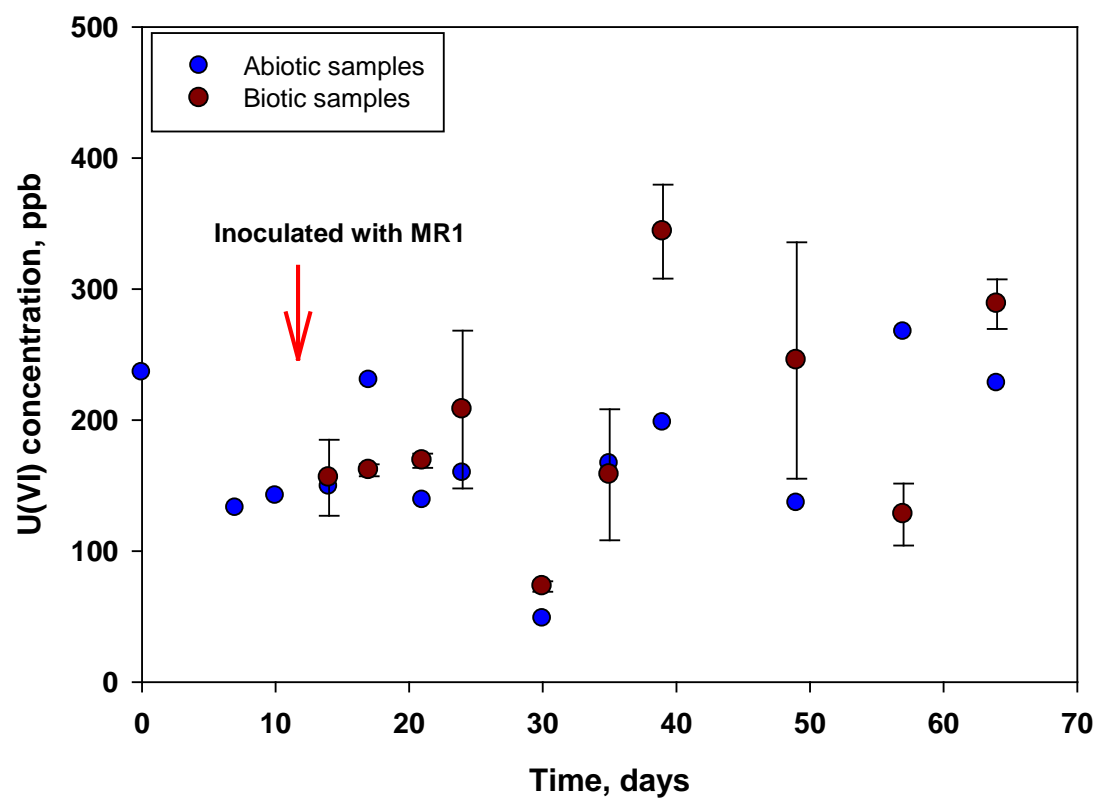

Figure 11. Uranium concentration as a function of time for bicarbonate-free samples.

The results of the measured U(VI) in the samples with bicarbonate free media did not show a significant statistical difference before and after inoculation with bacteria (confidence level 95\%, p-value $=0.468$ ). Data suggests that Shewanella Oneidensis $M R-1$ is not a factor that contributes with dissolution of autunite mineral by inducing the release of $\mathrm{U}(\mathrm{VI})$ into the aqueous phase in the absence of bicarbonate (inoculated on day 10) as observed on Figure 11. For the media amended with bicarbonate ( 3 and $10 \mathrm{mM}$ ), the measured concentration of $\mathrm{U}(\mathrm{VI})$ on the biotic samples in the aqueous phase had a sharp increase as soon as inoculated with bacteria (day 10); this might be attributed to autunite dissolution by bacterial cells in their search for phosphorous necessary to maintain their metabolic activities. If compared to the corresponding abiotic controls the steady state of biotic samples was achieved until the concentration of released $\mathrm{U}(\mathrm{VI})$ was 3-6 times higher. Although anaerobic conditions were carefully kept throughout the development of the 
experiment, no bioreduction of uranium was observed in bicarbonate amended samples (Figure 12 and 13) and instead the concentration of uranium in the media solutions remained stable along the entire experiment (63 days).

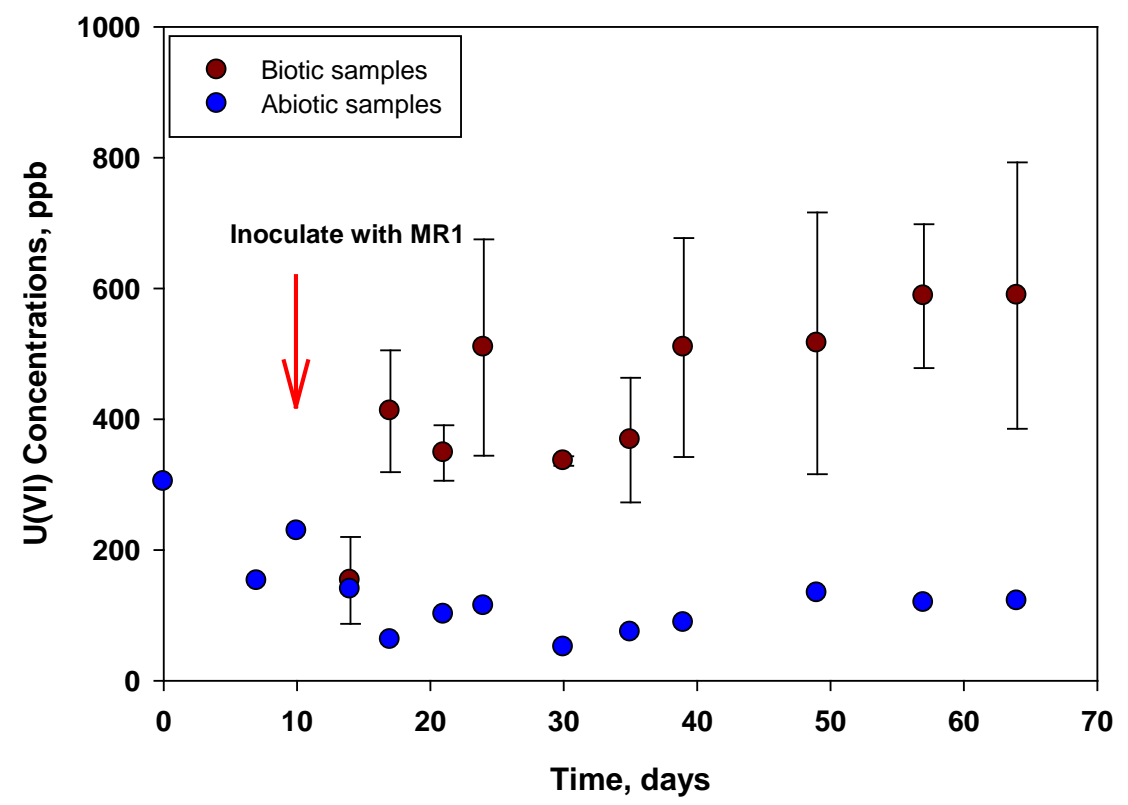

Figure 12. Uranium concentration as a function of time for samples amended with $3 \mathrm{mM}$ bicarbonate. 


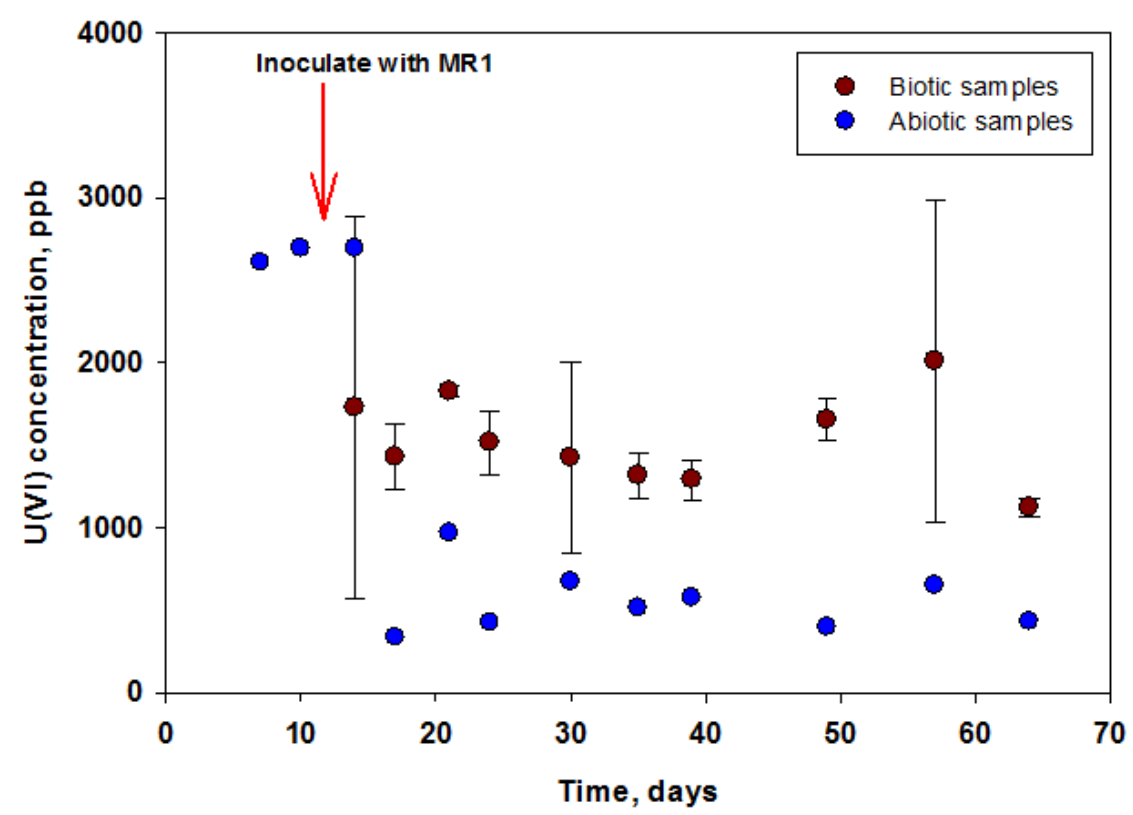

Figure 13. Figure 6. Uranium concentration as a function of time for samples amended with $10 \mathrm{mM}$ bicarbonate.

Figure 14 summarizes U(VI) dissolution for all three concentrations of $\mathrm{HCO}_{3}{ }^{-}$included in this study in order to compare aqueous release of U(VI) in biotic samples. Despite the fact that no bioreduction of U(VI) was observed in any of the conditions studied, the degree of uranium release among the different conditions in the presence of Shewanella Oneidensis MR-1 differed significantly. The results confirm that the higher the bicarbonate the higher the rate of dissolution of uranium bearing minerals, since there was a progressive increase in uranium release as the concentration of bicarbonate in the samples increased (pvalue=0.001 among all groups for confidence interval 95\%). 


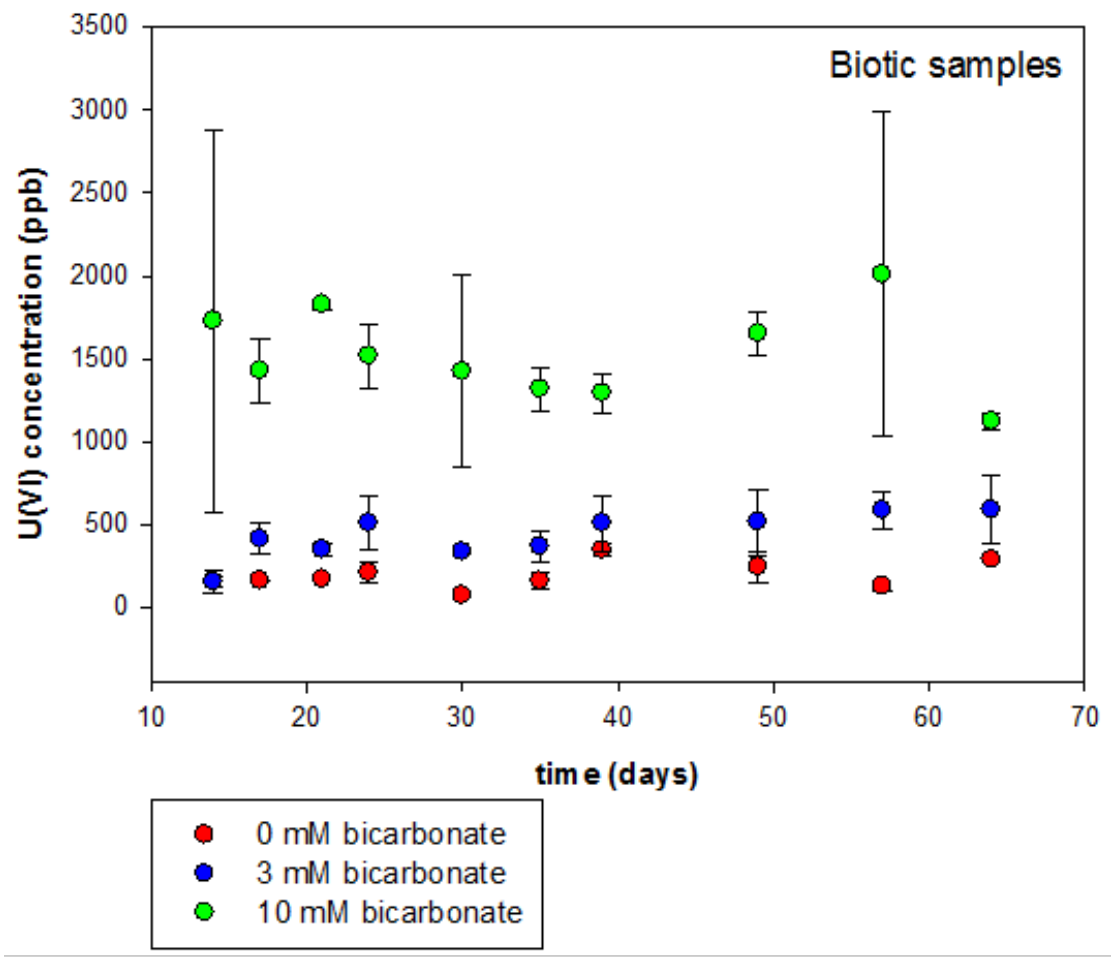

Figure 14. Uranium concentration in the aqueous phase in the presence of Shewanella Oneidensis as a function of time, for three different bicarbonate conditions.

To continue with chemical analysis, ICP-OES instrument was used to measure Ca and P released in the aqueous phase as a result of autunite dissolution. The results for bicarbonatefree media is shown in Figure 15 and indicates that Ca released in the media had a slight decrease after inoculation although biotic samples had a similar pattern compared with controls throughout the experiment ( $\mathrm{p}$-value $=0.476$ ). Similar behavior was observed in low bicarbonate concentration $3 \mathrm{mM} \mathrm{HCO}_{3}{ }^{-}$(p-value=0.867), presented in Figure 16 (35-55 ppm) and in high bicarbonate concentration $10 \mathrm{mM} \mathrm{HCO}_{3}{ }^{-}$(Figure 17) but with a little increase in the aqueous Ca measured ( $\mathrm{p}=0.867$, confidence interval $0.95 \%)$. As discussed 
in uranium results there is also a relation with higher concentration of bicarbonate in producing a higher Ca release in the aqueous phase.

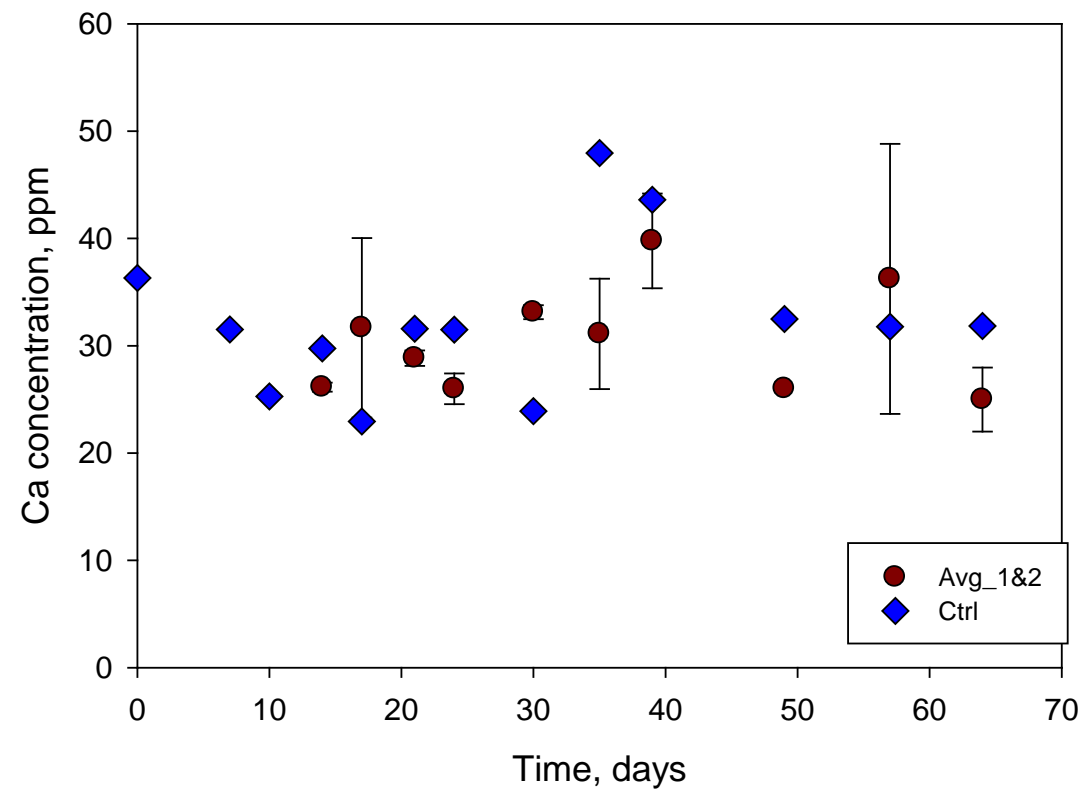

Figure 15. Calcium concentration as a function of time for bicarbonate-free samples. Red points represent biotic samples while blue points represent abiotic samples. 


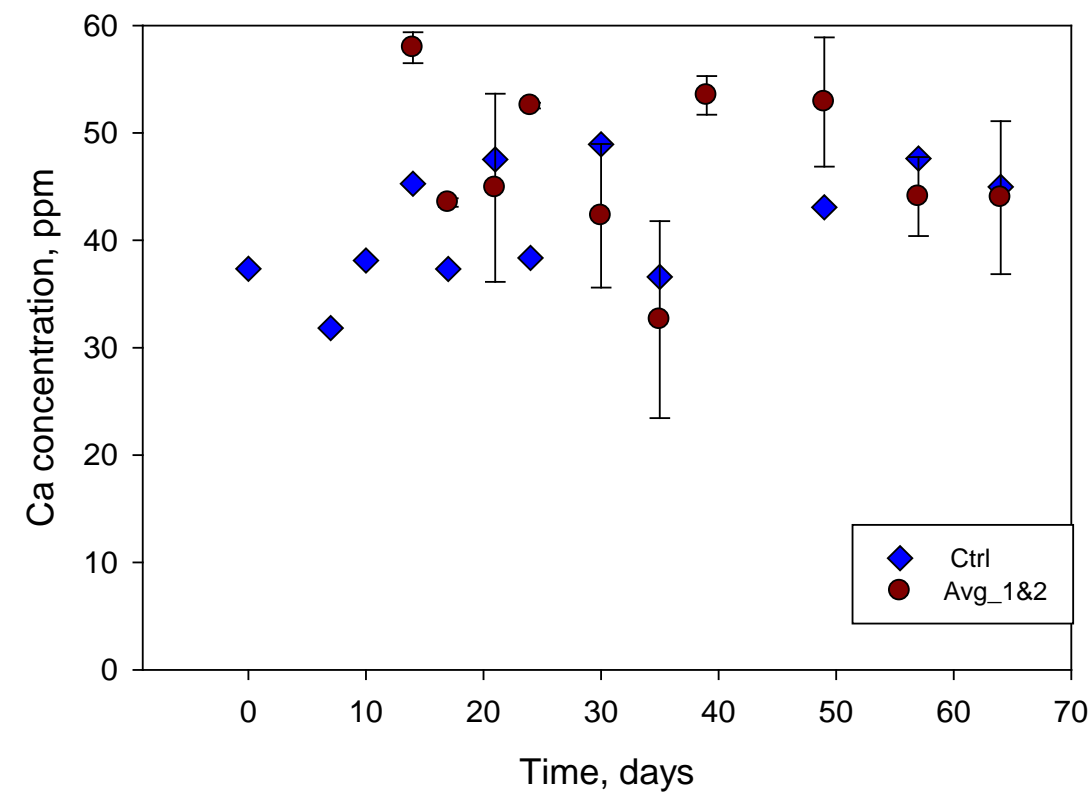

Figure 16. Calcium concentration as a function of time for samples amended with $3 \mathrm{mM}$ bicarbonate. Red points represent biotic samples while blue points represent abiotic samples.

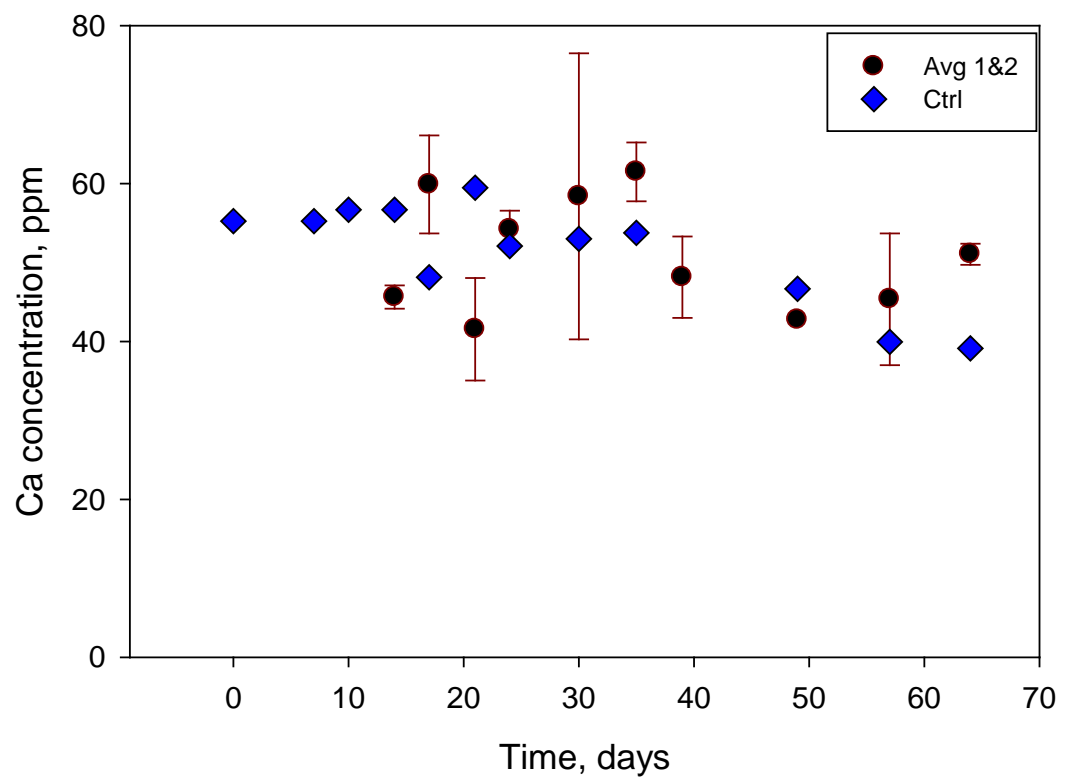

Figure 17. Calcium concentration as a function of time for samples amended with $10 \mathrm{mM}$ bicarbonate. Red points represent biotic samples while blue points represent abiotic samples. 
The monitoring of $\mathrm{P}$ content in the samples of this research was a key element since its part of the vital nutrients for bacteria. When measuring the P content released in the aqueous phase a high variation within the biotic duplicates was observed. Despite this finding the results were similar to Ca since there were no significant difference difference between biotic and abiotic samples in the three different concentrations of $\mathrm{HCO}_{3}{ }^{-}$evaluated (pvalue $=0.784$, $p$-value $=0.793$ and $p$-value $=0.644$ for bicarbonate free, $3 \mathrm{mM}$ and $10 \mathrm{mM}$ $\mathrm{HCO}_{3}{ }^{-}$media, respectively, confidence interval 95\%) as seen on the figures below.

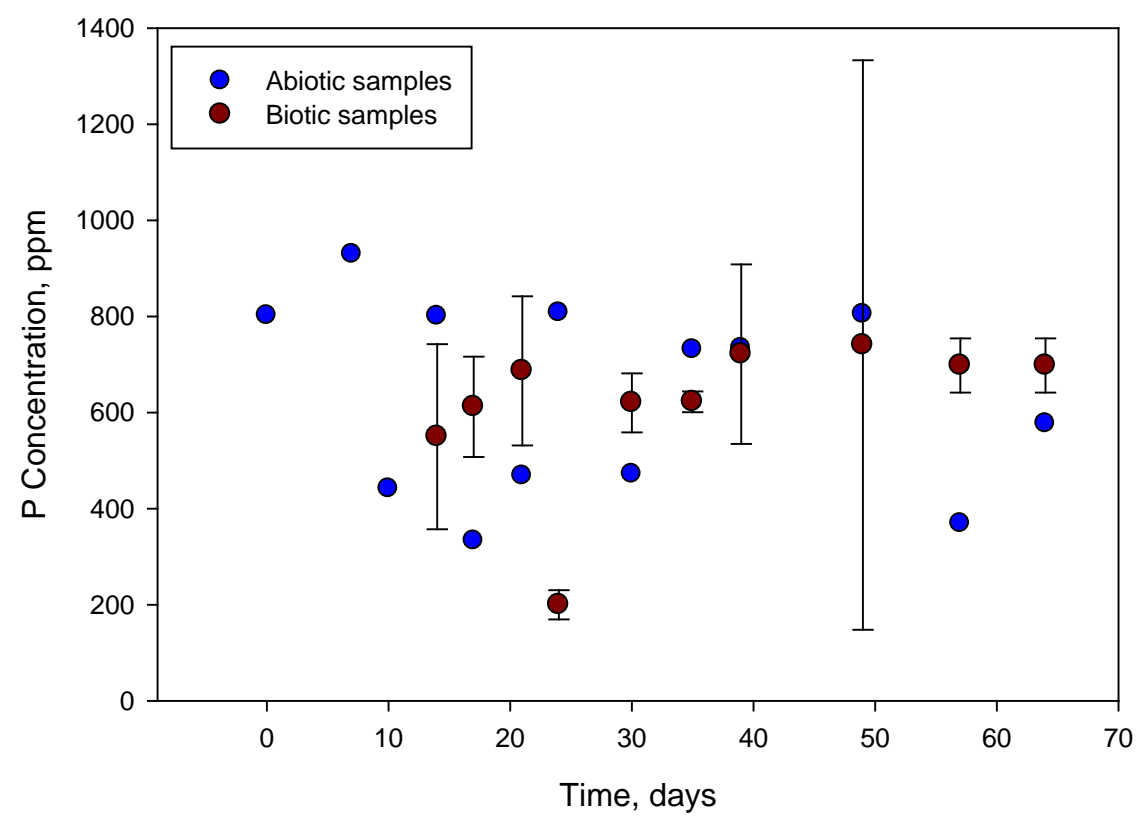

Figure 18. Phosphorous concentration as a function of time for bicarbonate-free samples. Red points represent biotic samples while blue points represent abiotic samples. 


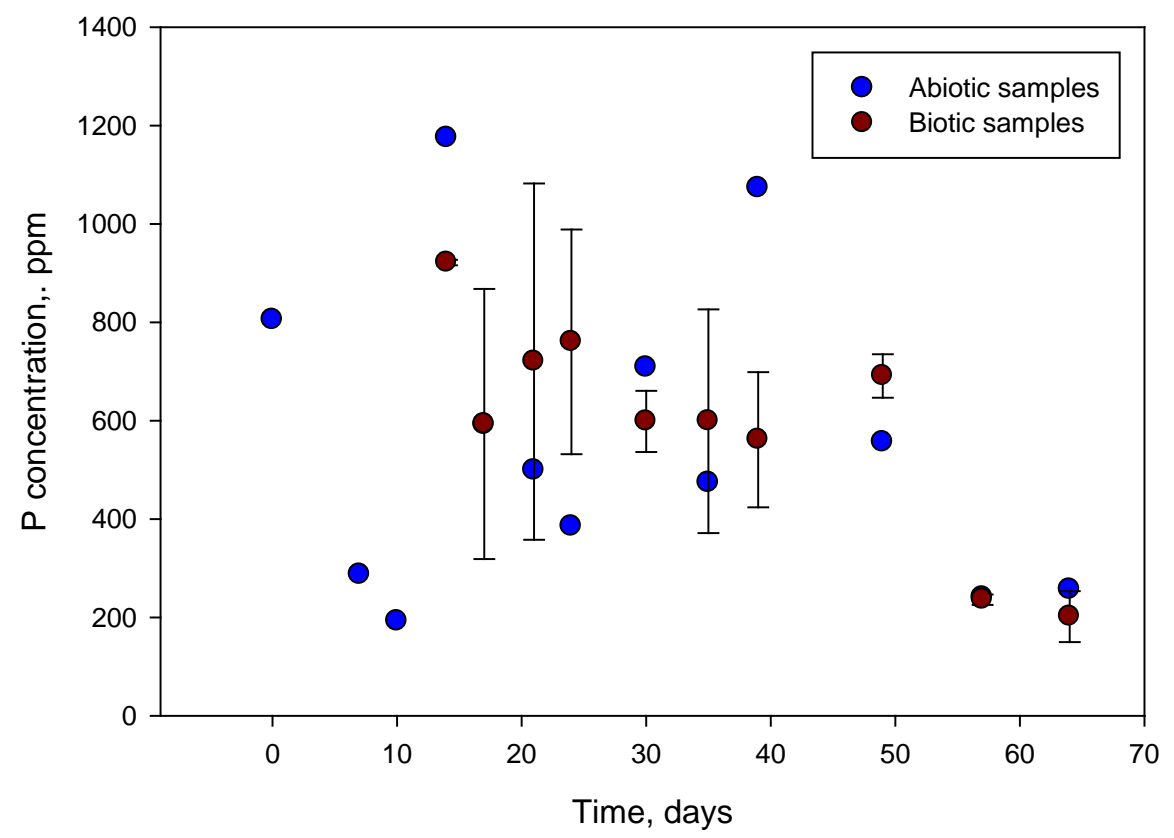

Figure 19. Phosphorous concentration as a function of time for samples amended with $3 \mathrm{mM}$ bicarbonate. Red points represent biotic samples while blue points represent abiotic samples.

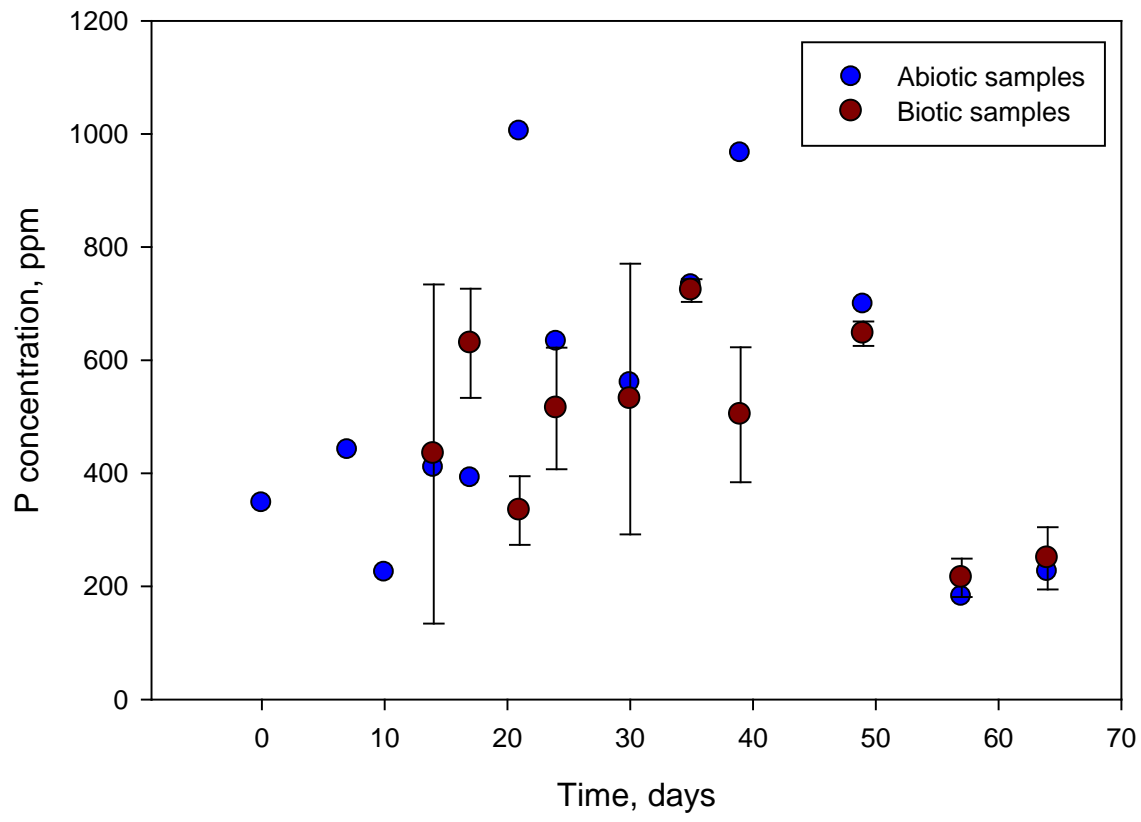

Figure 20. Phosphorous concentration as a function of time for samples amended with $10 \mathrm{mM}$ bicarbonate. Red points represent biotic samples while blue points represent abiotic samples. 


\section{Agar plating - Cell Viability}

Calculation of cell density was done by means of a hemocytometer with direct cell counting using light microscope. This was done in combination with agar plating to conduct cell viability analysis using the spread-plate method; this was performed at every sampling event. All biotic samples were initially inoculated with cell density of $10^{6}$ cells $/ \mathrm{mL}$ (log 6 cells $/ \mathrm{mL}$ ). Bicarbonate free media samples showed almost no variation in relation with the initial bacterial suspension inoculation (Figure 21). On the other hand, for the case of bicarbonate amended media, 3 and $10 \mathrm{mM} \mathrm{HCO}_{3}{ }^{-}$the increase observed in the data presented in Figure 21 was about 10-14 folds higher than initial cell density; values reached stability in the range of $\log [6.9-7.3] \mathrm{cell} / \mathrm{mL}$ at the final days of the experiment.

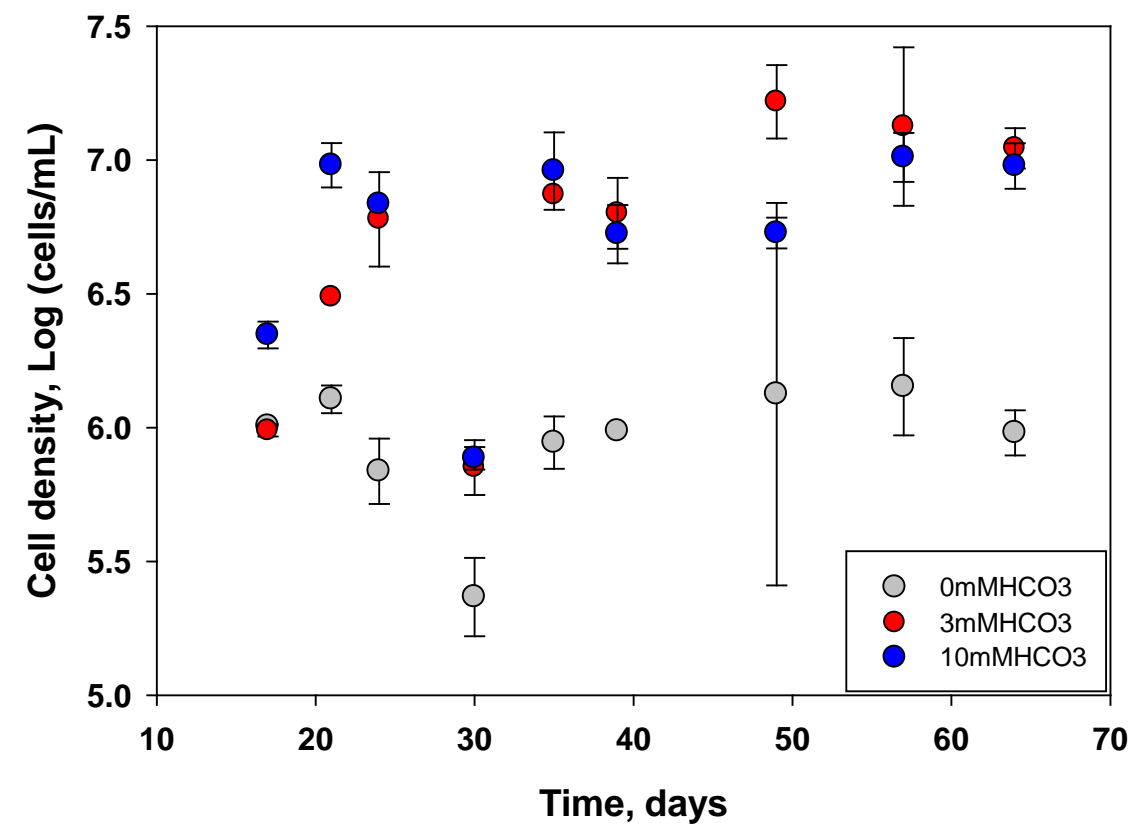

Figure 21. Changes in the direct cell counts for samples containing varying concentrations of bicarbonate. 
Cell viability was determined by counting the colony forming units $(\mathrm{CFU} / \mathrm{mL})$ and was used to be compared to the cell density calculated by direct cell counting. For bicarbonate free samples CFU was approximately $11.1 \%$ of viable cells out of a total cell density that correlates to only $1.1^{5} \pm 1.0^{5} \mathrm{CFU} / \mathrm{mL}$ and agar plates evidenced viable cells tendency to decrease over time (Figure 22). In the case of samples amended with bicarbonate media the scenario was different. For $3 \mathrm{mM}$ (Figure 23) and $10 \mathrm{mM} \mathrm{HCO}_{3}{ }^{-}$(Figure 24), the ratio between viable cells and total cell density had an increasing tendency to $30-31 \%$. The relation in increasing cell density for bicarbonate media was accounted in average to $1.0^{7}$ $-1.4^{7}$ cells/mL and consequently the amount of viable cells was determined to be in the range of $2.2^{6}-2.3^{6} \mathrm{CFU} / \mathrm{mL}$, which was significantly higher than that observed in bicarbonate free media samples.

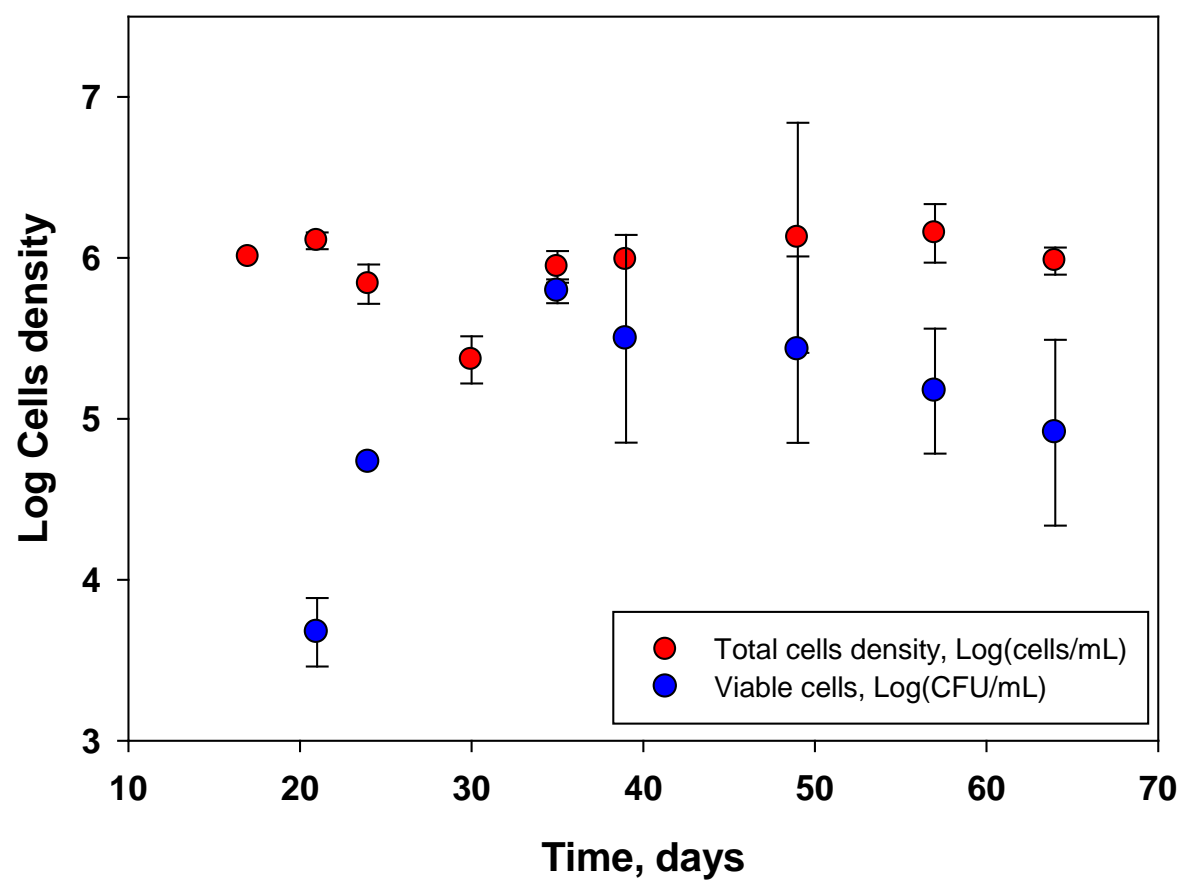

Figure 22. Results for the total cell density to viable cells for $0 \mathrm{mM} \mathrm{HCO}_{3}^{-}$. 


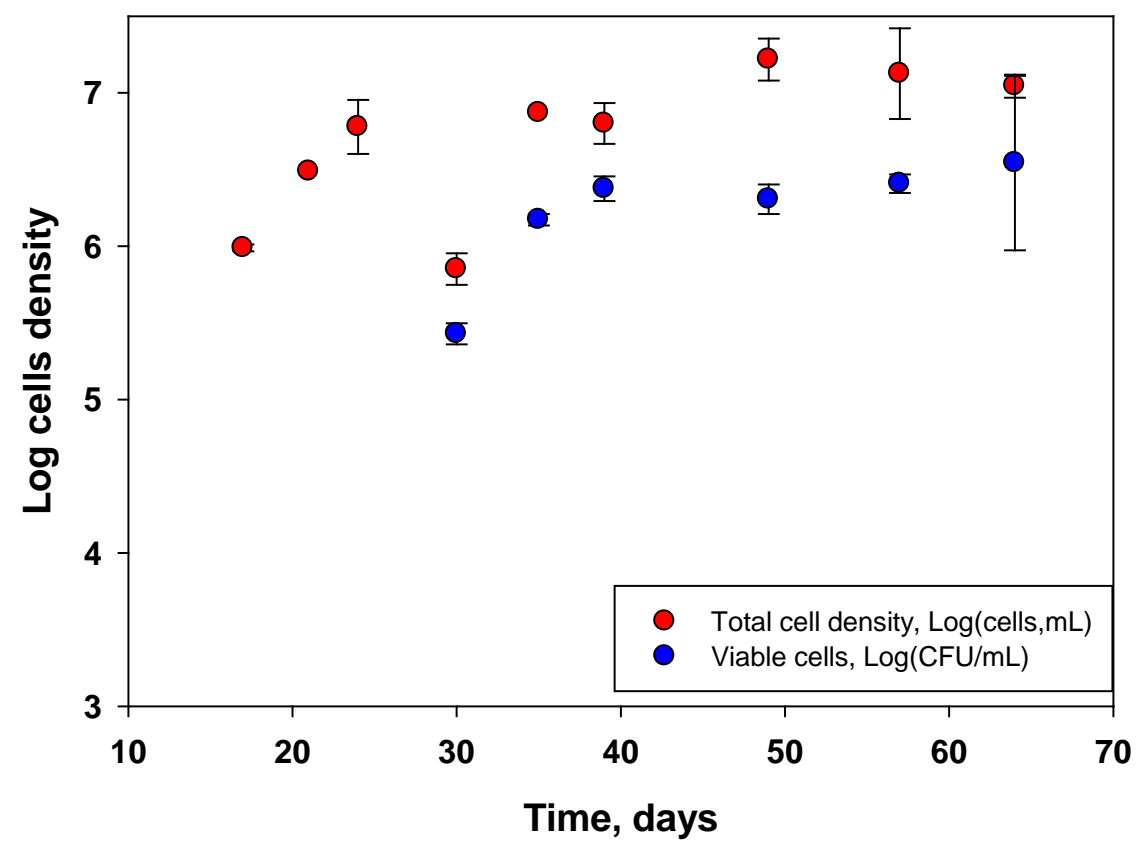

Figure 23. Results for the total cell density to viable cells for $3 \mathrm{mM} \mathrm{HCO}_{3}{ }^{-}$.

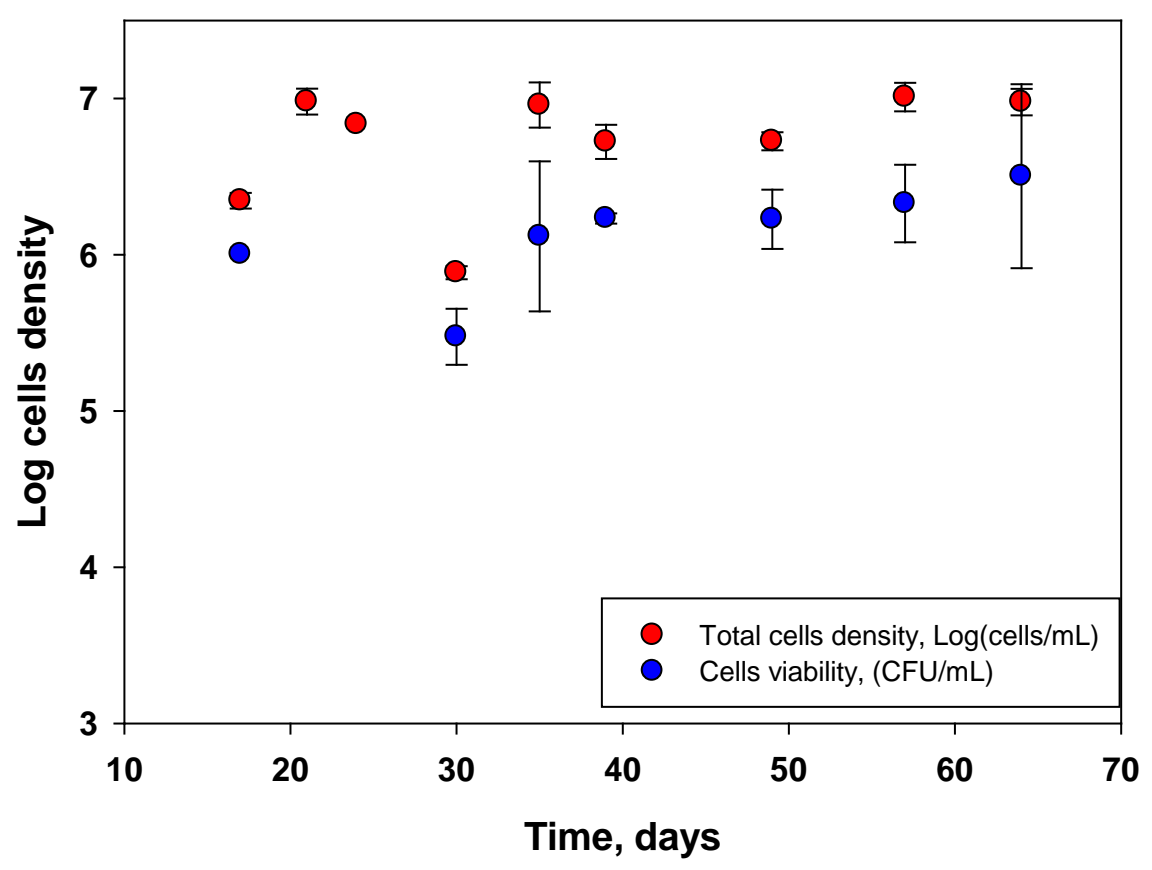

Figure 24. Results for the total cell density to viable cells for $10 \mathrm{mM} \mathrm{HCO}_{3}{ }^{-}$. 
The accountable increase in the total cell density and the amount of viable cells could be a sign that bacterial cells acclimatized to media and were able to withstand a highly toxic environment; such as uranium in the presence of bicarbonate ions. Results for the total cell density versus viable cells are presented in Figure 21, Figure 23 and Figure 24 for 0, 3 and $10 \mathrm{mM}$ bicarbonate media samples, respectively.

\section{pH supervision and protein analysis}

The $\mathrm{pH}$ of the reactors was monitored by measuring solutions $\mathrm{pH}$ directly at the vials on every sample event. For all the biotic samples at all $\mathrm{HCO}_{3}{ }^{-}$conditions tested, there was a spike in $\mathrm{pH}$ observed on day 21. On the other hand for abiotic samples, $\mathrm{pH}$ remained fairly constant and unchanged until the end of the experiment (Figure 25).

Facultative anaerobic bacteria in the presence of a terminal electron donor $\left(\mathrm{O}_{2}\right)$ can convert sugars to $\mathrm{CO}_{2}$ through respiration (Lin, Bennett et al. 2005), whereas in the absence of a terminal electron donor, sugars can be converted into organic molecules through fermentation reactions (Sanchez, Bennett et al. 2005). In the case of Shewanella Oneidensis $M R$-1, the bacteria under aerobic conditions have been reported to produce no other products than $\mathrm{CO}_{2}$ (Pinchuk, Geydebrekht et al. 2011) which when dissolved in water forms carbonic acid, hence decreasing the $\mathrm{pH}$. On the other hand, Shewanella Oneidensis $M R-1$ has been reported to metabolically excrete acetate and formate when grown on lactate as a sole carbon source under anaerobic conditions and the production of $\mathrm{CO}_{2}$ was very limited [33, 34, 32 and 35]. Assuming that the release of $\mathrm{CO}_{2}$ is the determining factor for $\mathrm{pH}$ fluctuation, the limited release of $\mathrm{CO}_{2}$ scenario may be a possible explanation for the experimental results presented in Figure 25. 


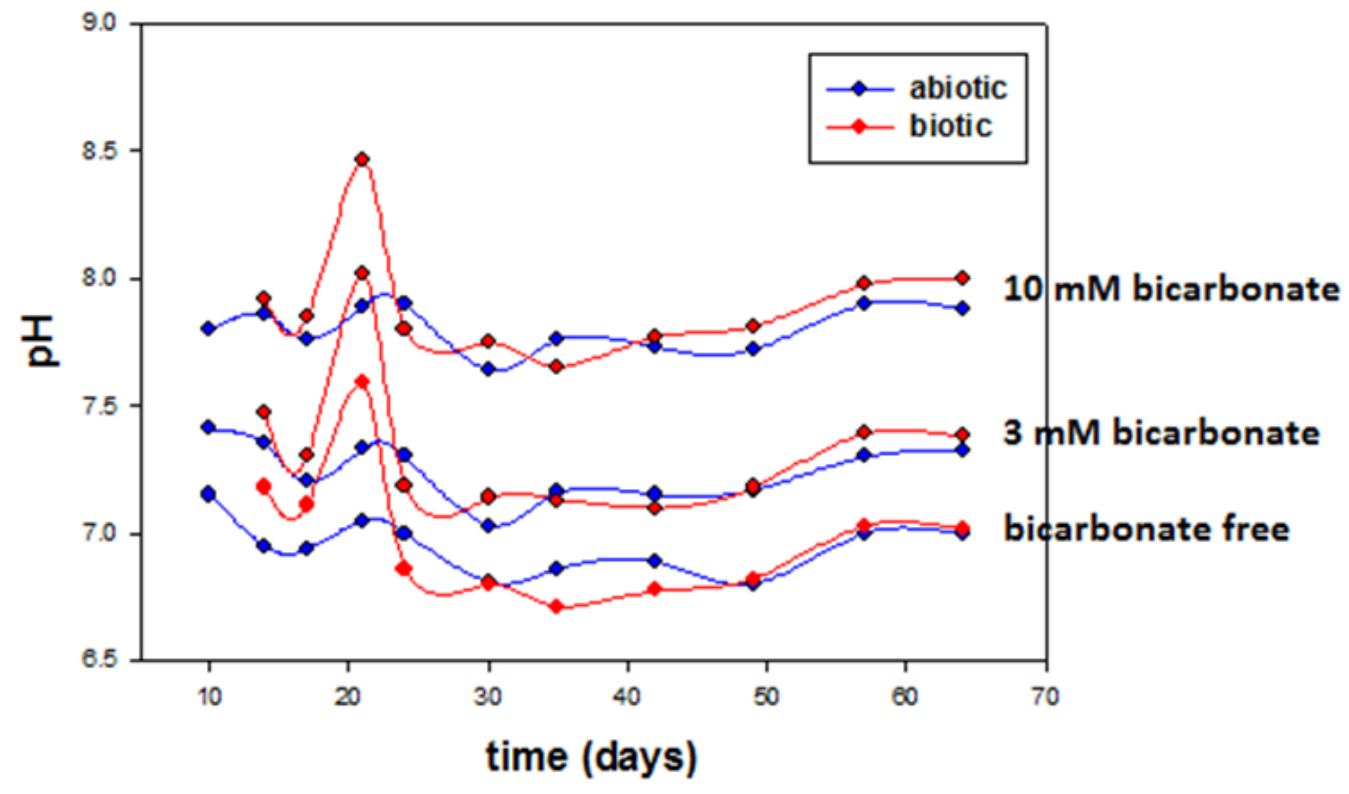

Figure 25. $\mathrm{pH}$ of autunite suspensions as a function of time. Red lines represent biotic samples and blue lines abiotic samples.

Protein analysis exposed an analogous pattern to $\mathrm{pH}$ measurements. There was a sharp increase in protein content observed on day 21 on the samples containing 3 and $10 \mathrm{mM}$ bicarbonate (Figure 26). Furthermore, a correlation was drawn between cell density suspensions of facultative anaerobic bacteria Shewanella Oneidensis $M R-1$ and the protein content that fits to a linear regression function (Figure 27). Based on the estimated linear regression function, it was possible to relate the experimentally determined protein content by converting to cell density on all the bicarbonate concentrations evaluated (Figure 28). At day 21 results suggested an increase in cell growth drawn by the correlation coefficient obtained from the protein content and the quantity of cells calculated in the media solutions. Cells cultivated in $10 \mathrm{mM} \mathrm{HCO}_{3}{ }^{-}$exposed an increase in cell density of 3 times higher than bicarbonate free media samples. The growth on cells represented by the sharp increase on 
protein concentration on day 21 also coincides with the $\mathrm{pH}$ peak point presented on the $\mathrm{pH}$ monitoring results. The variation on cells density had an interesting pattern such as the one developed in bicarbonate free media samples. The jump observed in the cell density was from $10^{6}$ to $10^{7.5}$ cells $/ \mathrm{mL}$, while in the other group of samples amended with $3 \mathrm{mM}$ and $10 \mathrm{mM}$ bicarbonate media the observed variation was greater; from $10^{6}$ cells $/ \mathrm{mL}$ to $10^{10}$ cells/mL.

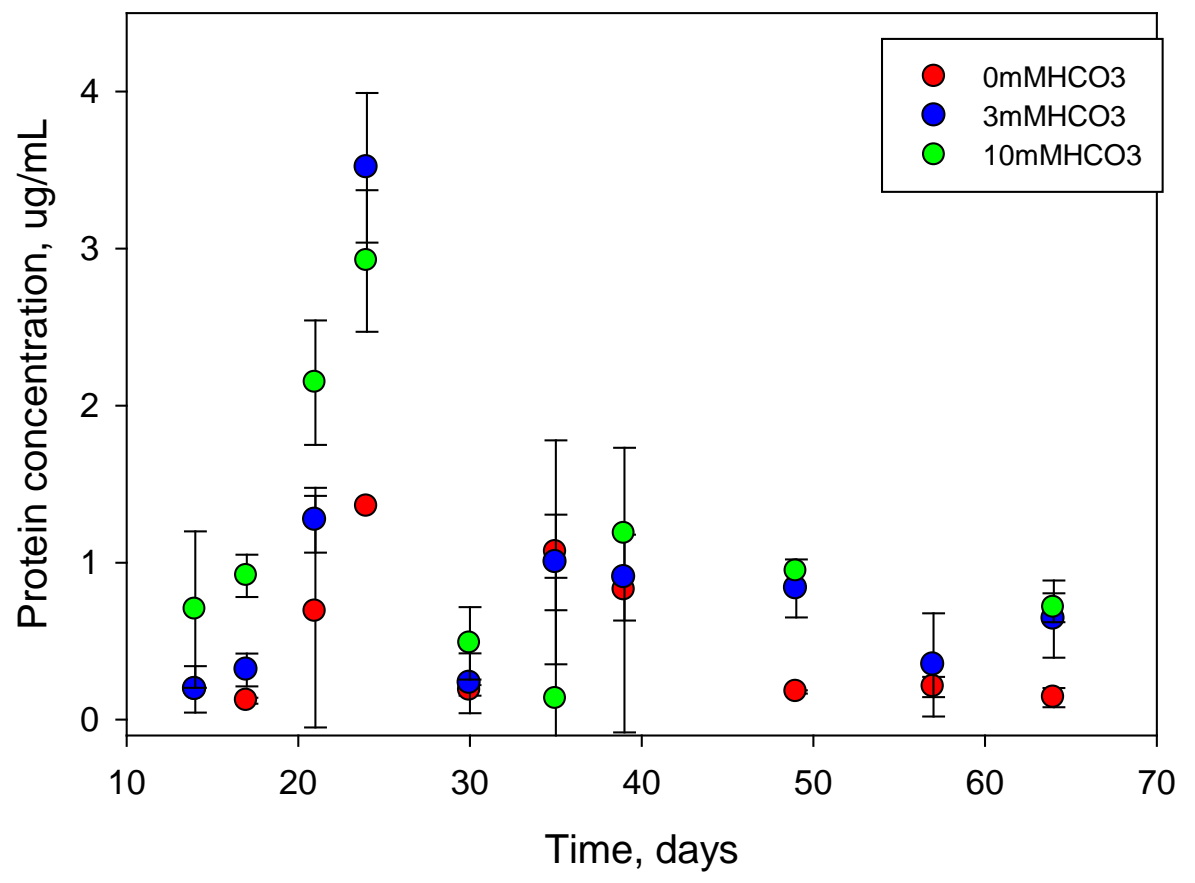

Figure 26. Protein concentration as a function of time for Shewanella oneidensis grown under anaerobic conditions. 


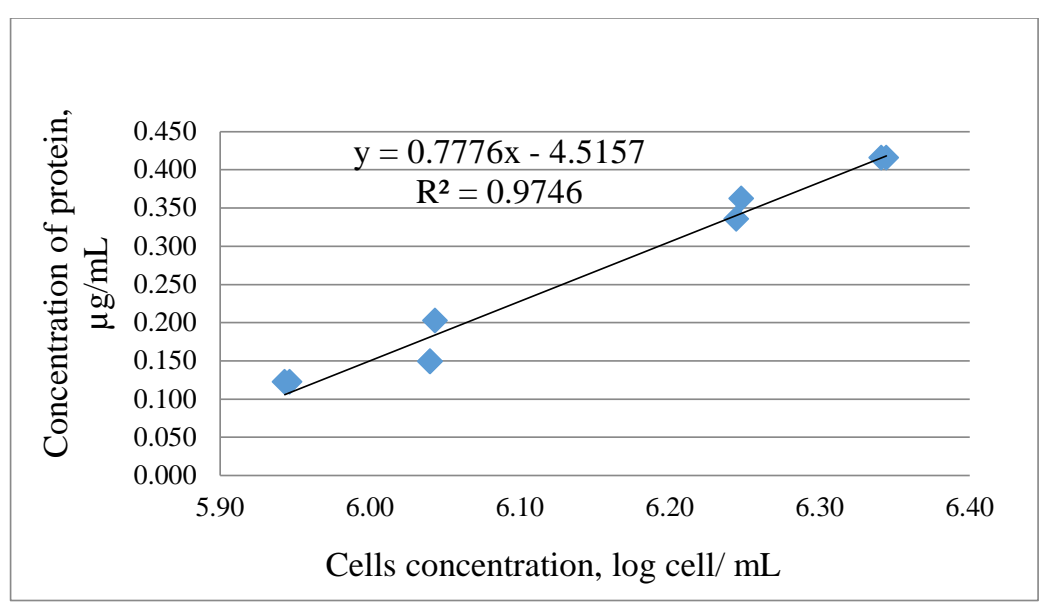

Figure 27. Correlation between cell density of Shewanella oneidensis MR-1 and protein content.

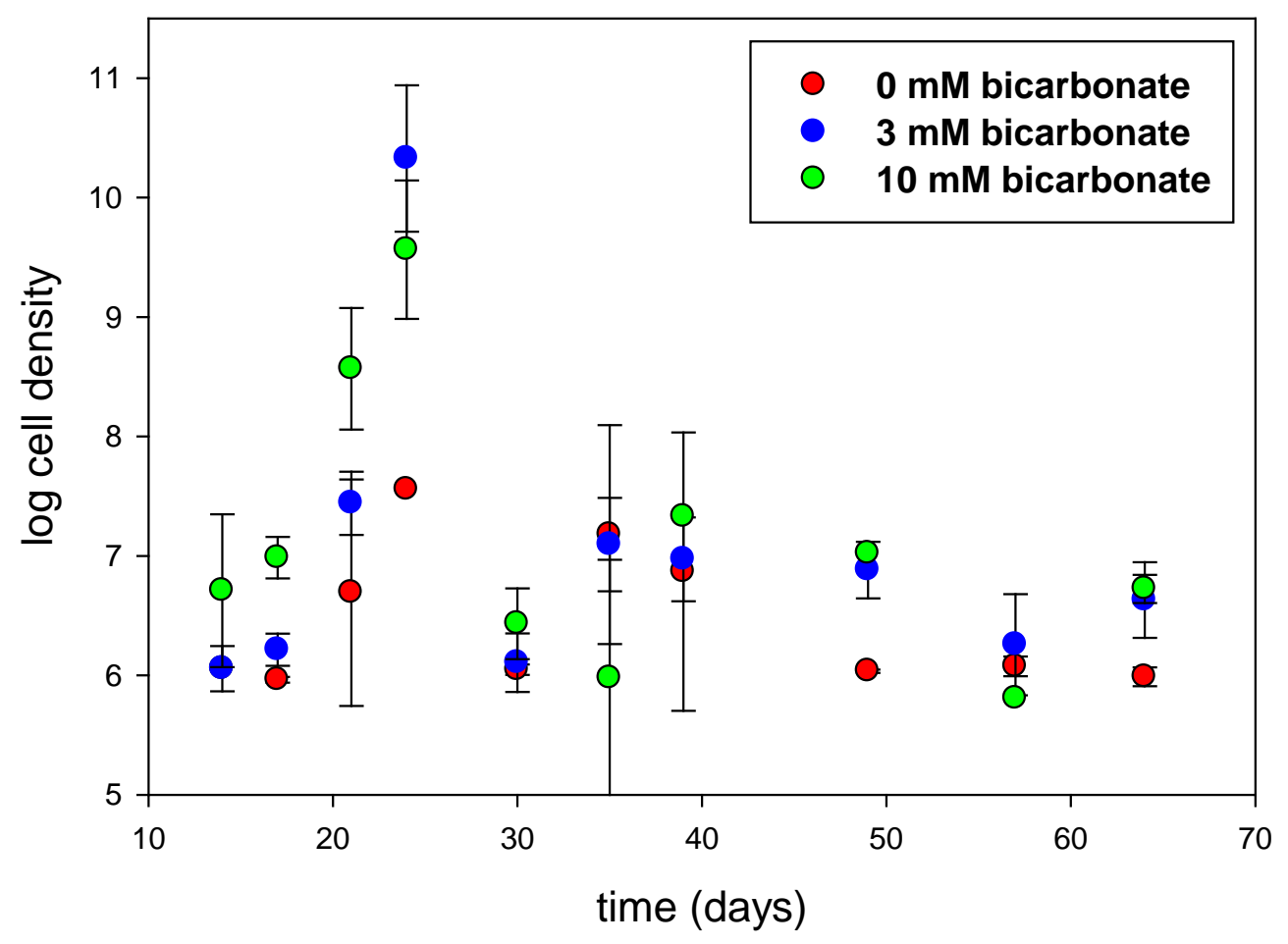

Figure 28. The variation of cell density (logarithmic scale) as function of time.

Theoretically the cell density calculated in Figure 28 corresponds to total cell density, that contemplates the addition of both viable and non-viable cells but it must be acknowledged that the nature of the protein determination protocol does not allow for the estimation of viable and non-viable cells. The calculated cell density from the total cell density can be 
perceived as overestimated if compared to direct visual cell density counting done over the agar plates. This might be due to the fact that in the Figure 28 the calculations were made on bacterial culture medium on biotic vials and there could be chance that exposure to uranium affected the cell physiology and protein content. Which might have resulted in changes of protein masses (Khemiri, Carriere et al. 2014). Therefore the correlation drawn from cell density and protein content for the control cells grown in culture media might not apply for cells exposed to uranium.

\section{SEM-EDS analysis and speciation studies}

When samples were observed with SEM, images revealed destruction of autunite mineral as an outcome of bicarbonate effect and bacterial activity (Figure 29) and Table 3 show information about the distribution (\%) of the elements in the sample. In the case of bicarbonate free samples no bacteria was observed on the mineral surface. This finding may support the fact that there was no uranium release in the aqueous phase (Figure 30) due to bacterial interactions. For the samples amended with 3 and $10 \mathrm{mM} \mathrm{HCO}_{3}{ }^{-}$bacterial cells were clearly observed on the autunite surface (Figure 32). Previous studies described how bacteria can attach on the mineral surfaces through specific structures called extracellular polymeric substances (EPS), comprised mostly of saccharides, proteins and secondary DNA and lipids (Donlan 2002). However, no extensive biofilm was observed (covering most of the surface or creating vertical layer formations). Shewanella Onedeinsis MR-1 studies on metabolism have reported that the formation of an extensive film is necessary for metal reduction which is regulated by the presence of oxygen (McLean, Pinchuk et al. 2008, Wu, Cheng et al. 2013). This research was conducted in anaerobic 
conditions. Hence, the absence of an extensive biofilm as no evidence of bioreduction may be justifiable.

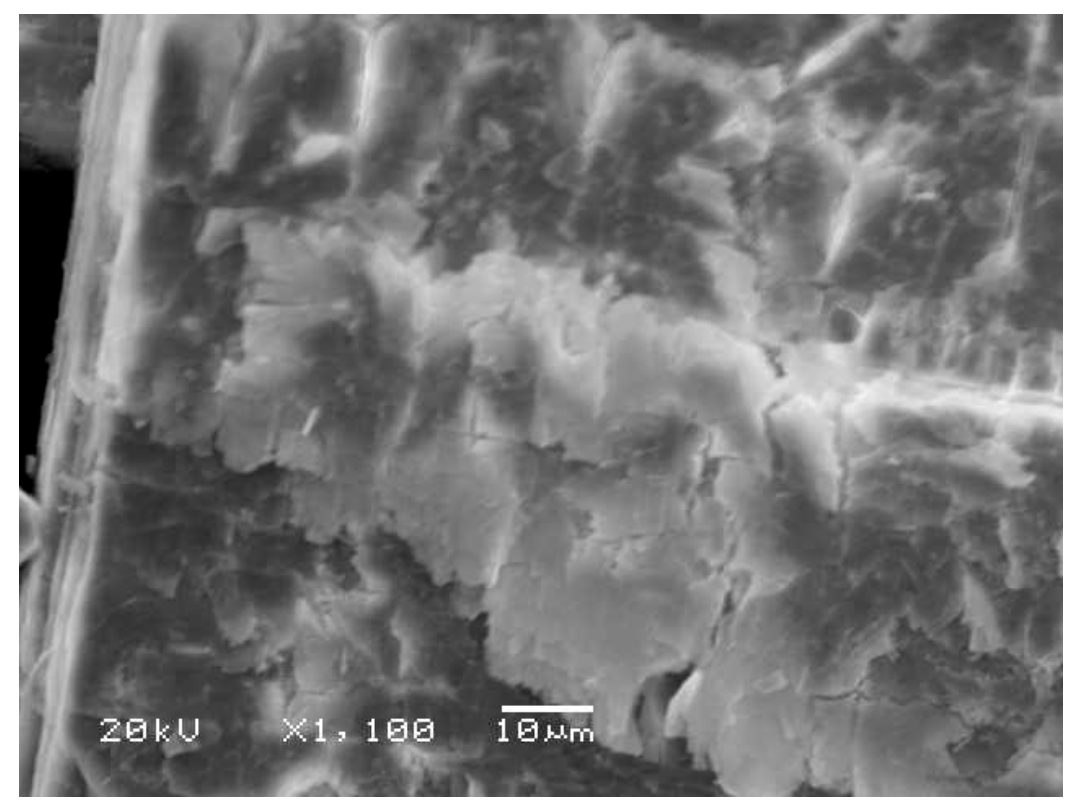

Figure 29. SEM image revealing structural damage of autunite and associated elemental composition by EDS analysis.

Table 3. Elemental analysis and energy distribution of sample shown on figure 29.

\begin{tabular}{|c|c|c|}
\hline Element & Wt\% & At\% \\
\hline $\boldsymbol{C K}$ & 01.43 & 07.80 \\
\hline $\boldsymbol{O K}$ & 14.19 & 57.90 \\
\hline $\boldsymbol{N a K}$ & 00.55 & 01.57 \\
\hline $\boldsymbol{P K}$ & 04.28 & 09.03 \\
\hline $\boldsymbol{C a K}$ & 01.39 & 02.26 \\
\hline $\boldsymbol{U L}$ & 78.15 & 21.44 \\
\hline Matrix & Correction & ZAF \\
\hline
\end{tabular}

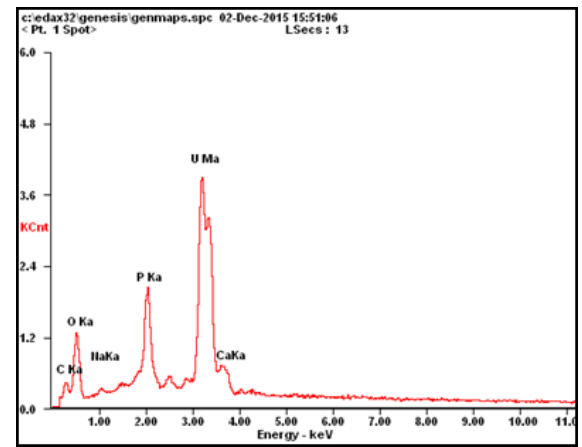




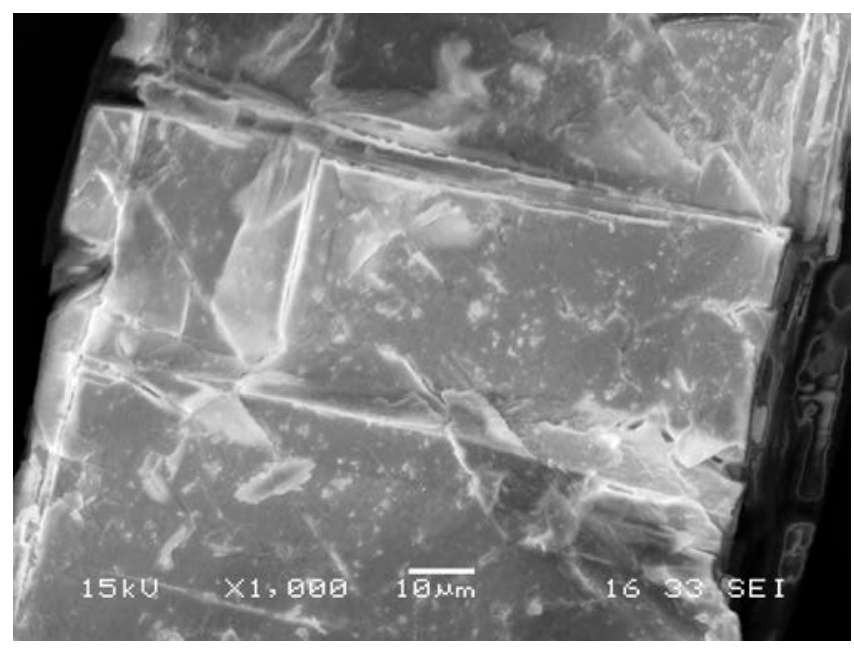

Figure 30. SEM image from autunite mineral related to a bicarbonate free sample.
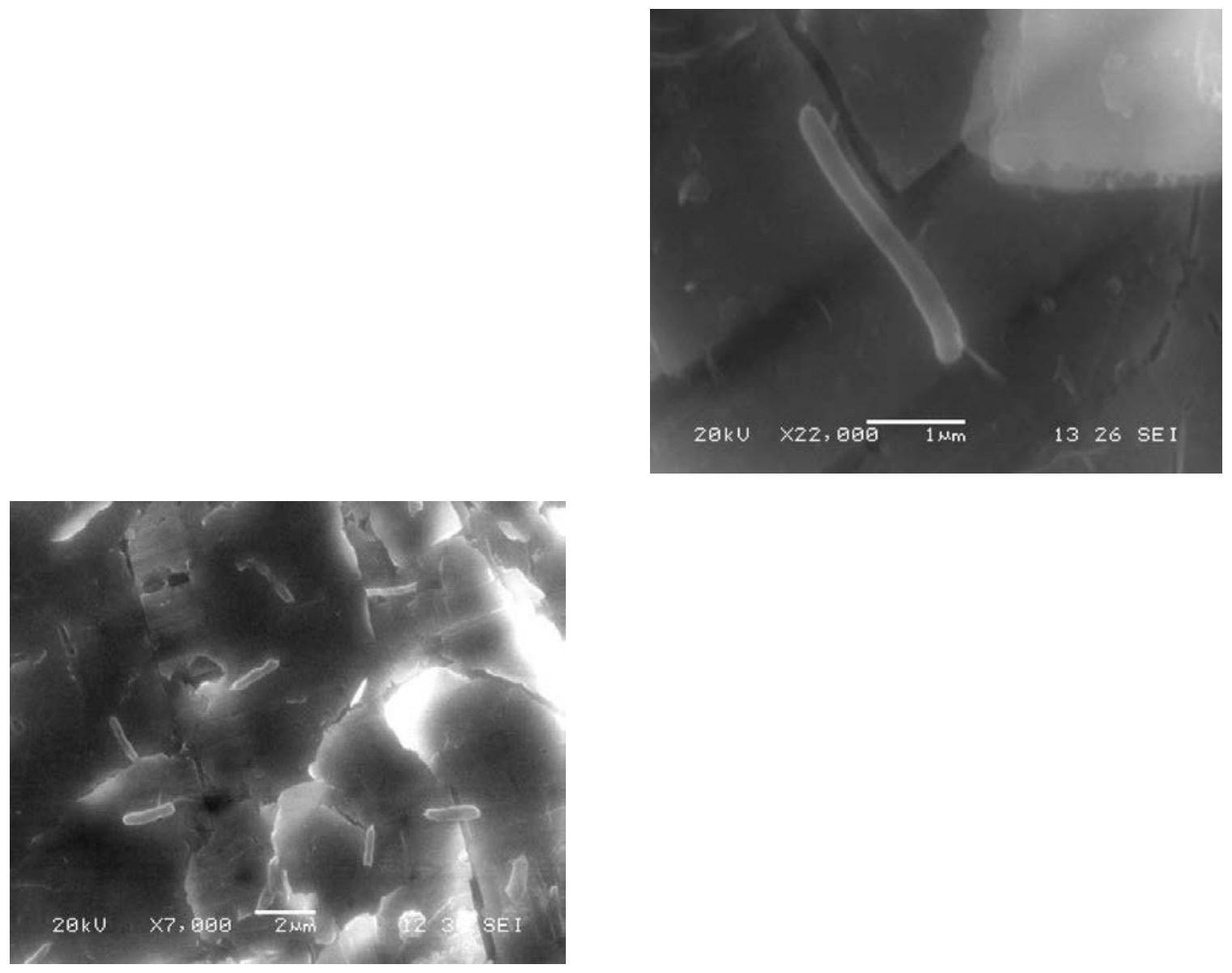

Figure 31. Bacterial activity on the surface of autunite. 


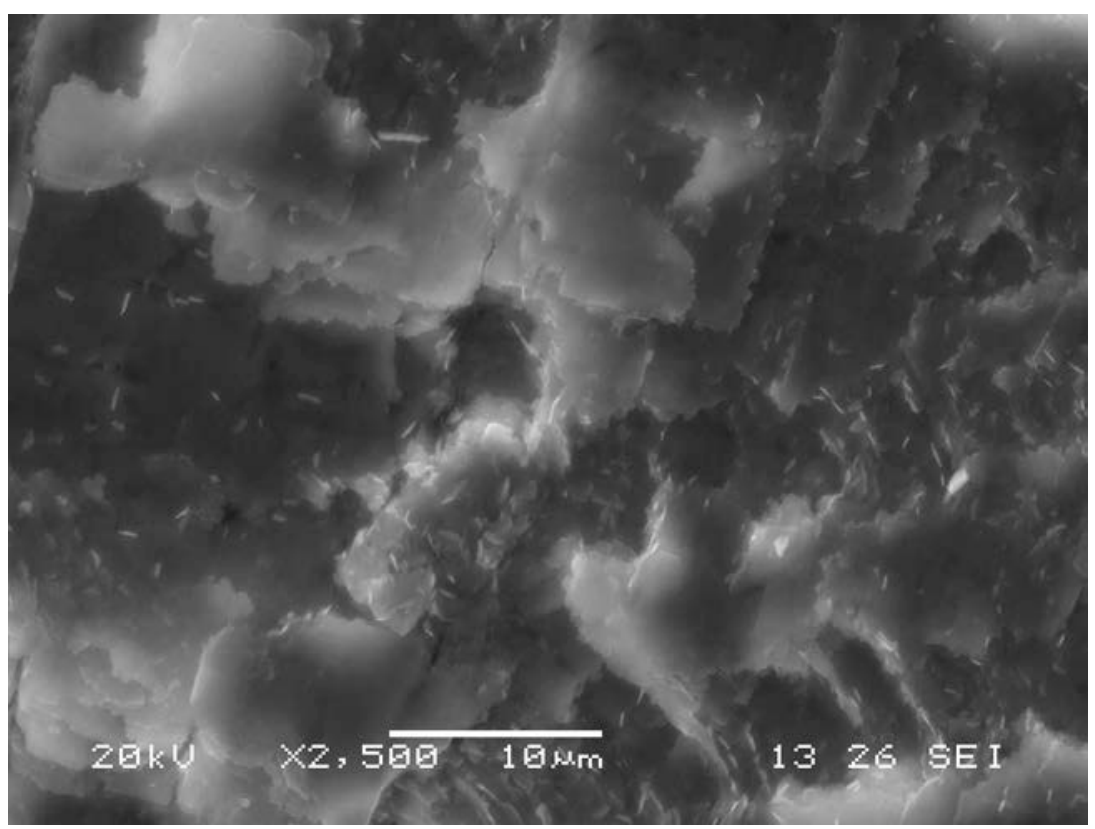

Figure 32. Observed bacteria cells on autunite in $10 \mathrm{mM} \mathrm{HCO}_{3}{ }^{-}$media.

Recent investigations studied the formation of the biofilm by Shewanella Oneidensis MR1 and found that the initial layer of the biofilm was produced by bacteria until the coverage of the surface and, consequently the formation of vertical towering biofilm structures (Thormann, Saville et al. 2004). Furthermore, acetate and lactate have been reported to be less effective stimulants for $\mathrm{U}(\mathrm{VI})$ reduction, whereas more complex organic electron donors have been directly correlated to the ability of DMRB to reduce U(VI) (Barlett, Moon et al. 2012).

The images obtained from SEM also revealed the formation of secondary minerals (Figure 33), predominantly the creation of uranyl phosphates and uranyl carbonates lining the surface of the autunite mineral. The release of $\mathrm{U}$, Ca and P saturate the aqueous phase and as a result secondary minerals are formed under the different conditions studied. Another 
image showing possible secondary minerals is Figure 34 with its correspondent EDS elemental (Table 4) analysis, that denotes that the uranyl species are the highest compositions found within the sample.

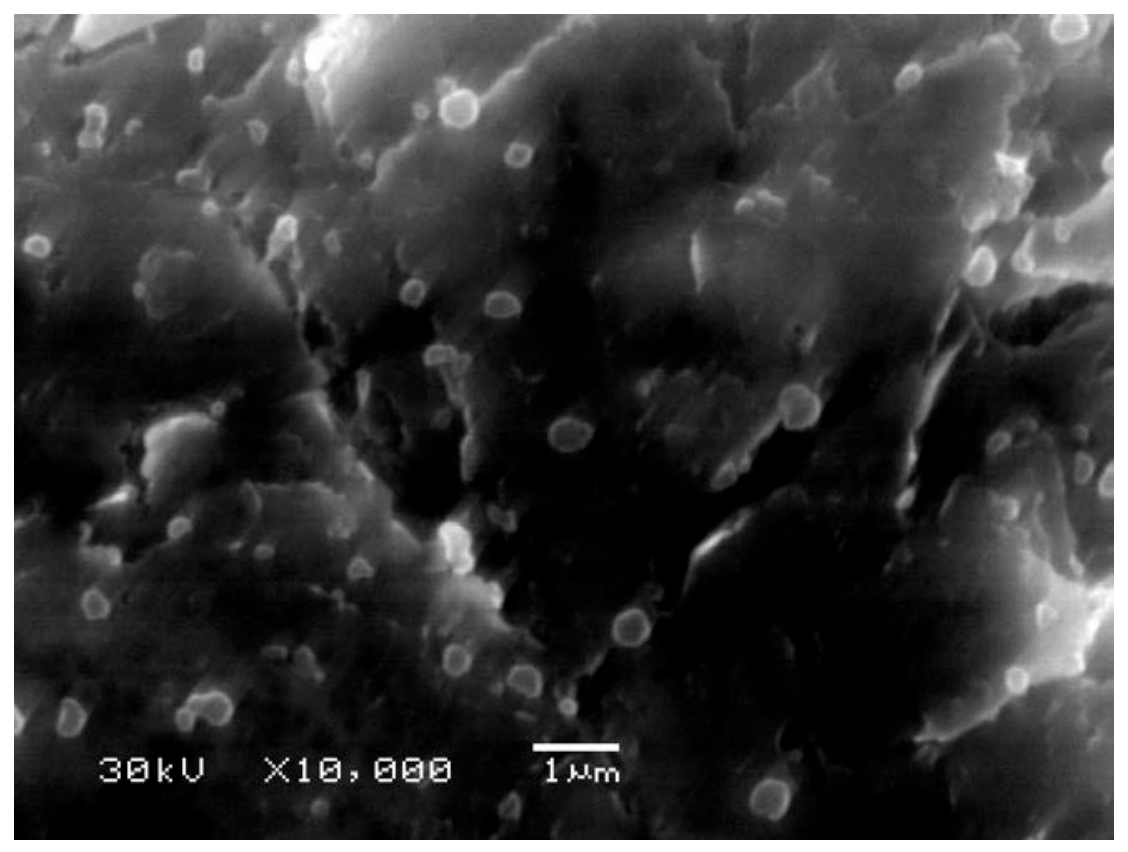

Figure 33. Secondary minerals observed on the surface of autunite. 


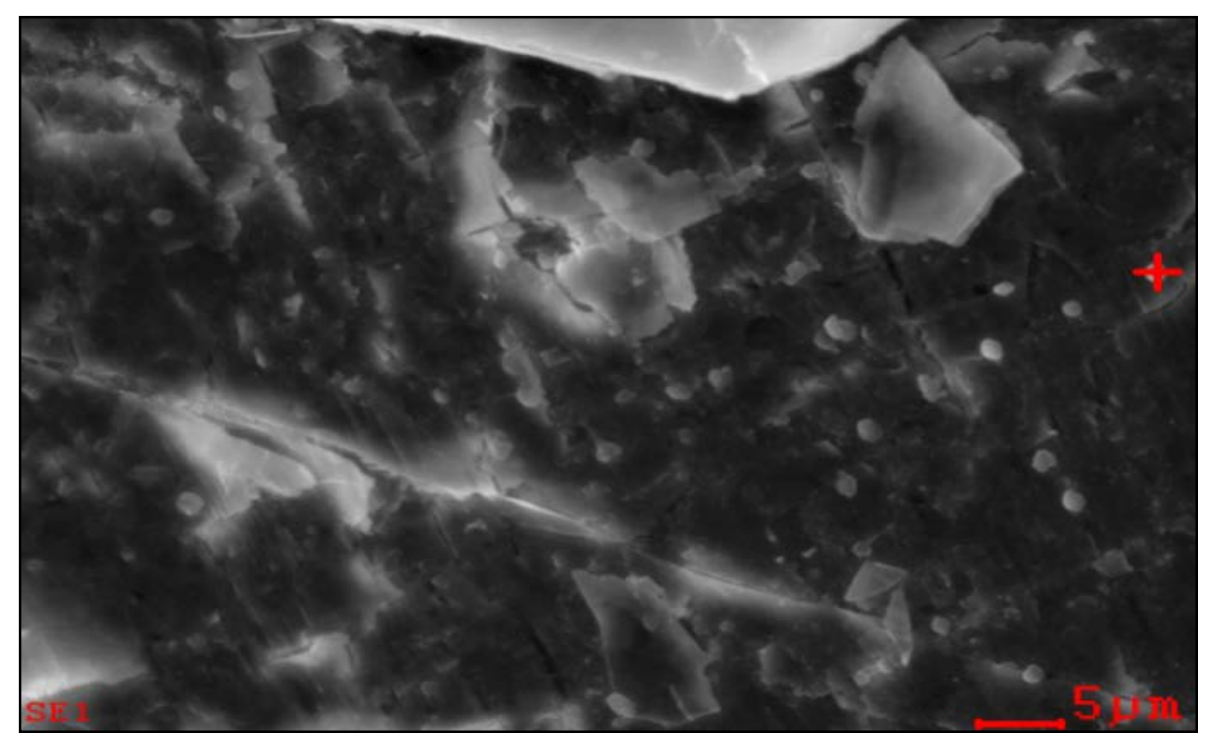

Figure 34. Secondary minerals with EDS analysis.

Table 4. EDS analysis over secondary minerals on shown on Figure 34.

\begin{tabular}{|c|c|c|}
\hline & Wt $\%$ & At $\%$ \\
\hline CK & 06.22 & 14.63 \\
\hline NK & 09.87 & 19.91 \\
\hline OK & 28.16 & 49.76 \\
\hline NaK & 00.65 & 00.80 \\
\hline PK & 05.92 & 05.40 \\
\hline UM & 42.96 & 05.10 \\
\hline CaK & 06.23 & 04.39 \\
\hline
\end{tabular}

Major factors that contribute to a higher rate of uranium release from natural autunite are the formation of uranyl-carbonate and calcium-uranyl-carbonate species. These complexes act as a driving force for uranyl detachment from mineral surfaces. Furthermore, natural autunite also forms a secondary Ca-P hydroxyapatite and uranyl phosphate minerals, which also serve as a driving force for the detachment of phosphate and calcium(SepulvedaMedina 2014). 
Visual Minteq had the input based on solution compositions from dissolution autunite mineral used in the experiment to predict the formation of secondary minerals as well as the soluble species under the experimental conditions tested (media amended with 20mM Na-HEPES and varying bicarbonate concentrations). The results with the mineral saturation indices predicted by speciation modeling software are presented in the Table 5 .

Table 5. Soluble and Saturated Species for All Three Conditions Studied (bicarbonate-free samples and samples amended with 3 and $10 \mathrm{mM}$ bicarbonate)

\begin{tabular}{|c|c|c|c|c|c|}
\hline \multicolumn{2}{|c|}{$0 \mathrm{mM}$ bicarbonate } & \multicolumn{2}{|c|}{$3 \mathrm{mM}$ bicarbonate } & \multicolumn{2}{|c|}{$10 \mathrm{mM}$ bicarbonate } \\
\hline $\begin{array}{c}\text { Solub } \\
\text { le }\end{array}$ & Precipitates & Soluble & Precipitates & Soluble & $\begin{array}{c}\text { Precipit } \\
\text { ates }\end{array}$ \\
\hline $\begin{array}{l}20 \% \\
\mathrm{UO}_{2} \mathrm{H}\end{array}$ & Hydroxylapatite & $\begin{array}{c}50 \% \\
\mathrm{Ca}_{2} \mathrm{UO}_{2}\left(\mathrm{CO}_{3}\right)\end{array}$ & Hydroxylapatite & $\begin{array}{c}92 \% \\
\mathrm{UO}_{2}\left(\mathrm{CO}_{3}\right)_{3}^{-4}\end{array}$ & $\begin{array}{l}\text { Hydrox } \\
\text { ylapatite }\end{array}$ \\
\hline $\mathrm{PO}_{4}$ & & 3 & & & \\
\hline & $\begin{array}{l}\text { Uranyl- } \\
\text { phosphate }\end{array}$ & & $\begin{array}{l}\text { Uranyl- } \\
\text { phosphate }\end{array}$ & & Uranyl- \\
\hline $\mathrm{UO}_{2} \mathrm{P}$ & & $\mathrm{CaUO}_{2}\left(\mathrm{CO}_{3}\right)_{3}$ & & $\operatorname{cavU}_{2}\left(\mathrm{CU}_{3}\right) 3$ & te \\
\hline $\mathrm{O}_{4}^{-}$ & & -2 & & 2 & \\
\hline & autunite & $\begin{array}{c}\sim 6 \% \\
\text { negatively } \\
\text { charged } \\
\text { uranyl } \\
\text { carbonate } \\
\text { complexes }\end{array}$ & autunite & & autunite \\
\hline
\end{tabular}


All of the cases were predicted with the saturation of hydroxyapatite (calcium phosphate mineral) and the uranyl phosphate minerals. However, the results of the elemental analysis showed that calcium, phosphorous and uranium seemed to be unaffected, supported by the fact that no decrease was observed along the duration of the experiment for any of these elements. The formation of secondary minerals could be associated with the decrease in the concentration of the elements as well as bioreduction in the case of uranium. Nevertheless, the apparent concentration of those elements remains the same and it might be because the rate of release of them into the aqueous phase is very similar to the rate of micro precipitation of secondary minerals, which removes these elements from the aqueous phase.

Moreover, the samples pertaining to bicarbonate free media and $10 \mathrm{mM} \mathrm{HCO}_{3}{ }^{-}$have soluble species that are primarily negatively charged entities; whereas for the samples amended with $3 \mathrm{mM} \mathrm{HCO}_{3}{ }^{-}$the negatively charged and the neutral $\mathrm{U}(\mathrm{VI})$ complexes are distributed in 50-50\%. Previous literature suggested that negatively charged uranyl complexes are less bioavailable to the cells and the least readily reducible fraction mostly due to electrostatic repulsions between negatively charged uranyl complexes and the bacteria cell surface (Sheng and Fein 2014, Belli, DiChristina et al. 2015). The scenario supports further potential explanation for the absence of bioreduction and the samples with bicarbonate free media and the ones amended with $10 \mathrm{mM} \mathrm{HCO}_{3}{ }^{-}$where most of the uranyl complexes are negatively charged.

On the other hand, previous research found that the point zero charge (pzc) of autunite is 5-6 (Wellman, Gunderson et al. 2007), which makes the net surface charge of autunite at 
pH 7.5 negative. Hence, it could be expected electrostatic repulsion by being the surface of the cells negatively charged as well as the autunite surface. Although, while making observations in SEM there was bacteria detected on the surface of the autunite mineral in the group of samples amended with bicarbonate; implying that under phosphorous limiting conditions bacteria may overcome the electrostatic repulsion and consequently liberate $\mathrm{P}$ from uranyl mineral phases to meet metabolic requirements. The quantity of bacteria observed on the mineral surface were not very high, which makes it not clear on what degree the described process takes place.

\section{CONCLUSIONS}

Experiments were conducted to evaluate the effect of facultative anaerobic bacteria Shewanella Onedidensis $M R-1$ on the dissolution of autunite mineral in the presence of varying concentrations of bicarbonate. In bicarbonate-free media the results of measured $\mathrm{U}(\mathrm{VI})$ before and after inoculation with bacteria did not show a significant difference. On the other hand, samples with media amended with bicarbonate, had a sharp increase (of 3 times compared to controls) on the measured $\mathrm{U}(\mathrm{VI})$ as soon samples were inoculated with bacteria.

Despite no bioreduction of U(VI) by DMRB was observed among all the conditions tested, results differed significantly. The higher the bicarbonate concentration the higher the rate of dissolution. Ca and P results had a similar trend between controls and biotic samples

and suggested an increasing release in the aqueous phase with increasing concentrations of bicarbonate. 
The initial cell density of inoculated vials was $10^{6}$ cells $/ \mathrm{mL}$ calculated by direct cell counting. At the final days of the experiment it reached $10^{7.3}$ cells/mL in samples containing bicarbonate. Cell viability determined by counting the CFU on agar plates, was compared to the cell density to monitor bacterial proliferation. For $0 \mathrm{mM} \mathrm{HCO}_{3}{ }^{-}$only $11 \%$ yielded as viable cells out of a total cell density and agar plates showed viable cells tendency to decrease in time. For the samples related to 3 and $10 \mathrm{mM} \mathrm{HCO}_{3}{ }^{-}$, the ratio between viable cells and total cel density had an increasing tendency of 33\%. The accountable increase in the amount of viable cells and total cell density could be because bacteria have acclimatized and the presence of bicarbonate have reduced $U$ toxicity on bacterial cells. $\mathrm{pH}$ monitoring showed a spike on day 21 while, for the rest of the experiment $\mathrm{pH}$ remained stable. This could be explained by the limited $\mathrm{CO}_{2}$ release, which implies no $\mathrm{pH}$ fluctuation. Protein analysis results was analogous to $\mathrm{pH}$ measurments; there was a sharp increase in protein content observed on day 21, although no relation has been found beteween this coincidence. Protein results showed that cells cultivated in $10 \mathrm{mM}$ $\mathrm{HCO}_{3}^{-}$had an increase in cell density three times higher than bicarbonate free media.

SEM revealed the destruction of autunite over time as an outcome of bacterial interactions. In the case of bicarbonate-free samples no bacterial cells were observed on the surface, this finding may support that there was no $\mathrm{U}(\mathrm{VI})$ release due to bacterial metabolic activities. On the other hand, samples amended with bicarbonate clearly showed bacteria on the surface and in some cases how they attach to mineral, although no biofilm was observed. Since $\mathrm{O}_{2}$ regulates the formation of this film for metal reduction, the absence of it might justify the no evidence on bioreduction. SEM images also revealed the possibility of 
secondary minerals formation. In accordance with SEM; speciation modeling (Visual Minteq) also suggested the formation of secondary minerals. All of the concentrations tested were predicted with hydroxyapatite (calcium phosphate mineral) and the unranyl phosphate minerals. However, the results of chemical analysis showed that $\mathrm{U}, \mathrm{Ca}$ a nd $\mathrm{P}$ seemed unaffected because no decrease of any of these elemets was observed throughout the experiment. The formation of secondary minerals could be associated with the decrease in the concentration of the elements as well as bioreduction in the case of U. Nevertheless, the apparent concentration of these elemts remains the same. It might be because the rate of release of them into th aqueous phase is very similar to the rate of secondary minerals formation, hence removing them from the aqueous phase. Furthermore it can be said that the removal of $\mathrm{U}, \mathrm{P}$ and $\mathrm{Ca}$ from the aqueous phase is due to the formation of secondary minerals and bioreduction, while autunite dissolution is reintroducing those elements in the aqueous phase resulting in an apparent equilibrium of those elements in the supernatant.

This work illustrated that although uranyl phosphates are considered to be sinks of uranium and therefore strong candidates for remediation strategies (Beazley, R. et al. 2007), the experimental results demonstrates their liability in the presence of bacteria.

\section{FUTURE WORK}

Further experiments on uranium-bacteria interactions conducted without autunite solids will help to investigate changes in protein content as a result of uranium exposure. It is suggested that batch experiments that will continue with this research are prepared with the

same concentrations of $\mathrm{U}, \mathrm{P}$ and $\mathrm{Ca}$ along with three different concentrations of bicarbonate amended media before inoculation with bacteria in mineral free media over 
the same duration of time. The purpose of the suggested design is to prove that there are two potentially antagonistic mechanisms with similar kinetics rates that are taking place. Since there will be no autunite dissolution the decrease in the elemental concentration in the aqueous phase will signify the existence of two antagonistic mechanisms, whereas if there is no variation in the concentrations it will suggest that the formation of secondary minerals is taking place to a very limited degree and the apparent equilibrium is nothing else but the mineral dissolution.

\section{PUBLICATIONS}

For this research work, previous batch experiments were performed in laboratory scale with the same concentrations of autunite mineral and one additional concentration of bicarbonate amended $\left(0,3,5\right.$ and10 $\left.\mathrm{mM} \mathrm{HCO}_{3}{ }^{-}\right)$media with the same objective and designed to be held in anaerobic conditions (Herrera, Anagnostopolous et al. 2016). The experiments were conducted with a planned schedule that contemplated days prior to inoculation with facultative anaerobic bacteria Shewanella Oneidensis $M R-1$, as well as days after bacteria equilibrated with media solution and sampling events for the same period of time. The main difference between actual and previous experiments, was that the bioreactors used were sterile $100-\mathrm{mL}$ serum bottles prepared in triplicate for each bicarbonate concentration tested and that bottles were crimp-sealed with rubber stoppers which kept cells under oxygen restricted conditions since no anaerobic chamber was used. One of the main drivers to evaluate the redesign of the experiment was to achieve strictly anaerobic conditions. Another reason was to prevent cross-contamination while punching 
the caps of the bottles with syringes for collecting samples. Instead it was replaced by the introduction of sacrificial vials.

The procedures of analysis used on oxygen restricted conditions were similar to the one presented in this thesis. Since oxygen was restricted on the previous experimental design, the results also differed. The summary of the experimental procedures and outcome was written in a paper format that was presented in the Waste Management conference 2016 held in Phoenix, Az. The draft is on review period to be formally accepted. 


\section{REFERENCES}

Bachmaf, S., B. Planer-Friedrich and B. J. Merkel (2008). "Effect of sulfate, carbonate, and phosphate on the uranium(VI) sorption behavior onto bentonite." Radiochimica Acta 96(6): 359-366.

Barlett, M., H. S. Moon, A. A. Peacock, D. B. Hedrick, K. H. Williams, P. E. Long, D. Lovley and P. R. Jaffe (2012). "Uranium reduction and microbial community development in response to stimulation with different electron donors." Biodegradation 23(4): 535-546.

Beazley, M. R., S. P., W. S. and T. M. (2007). "Uranium Biomineralization as a Result of Bacterial Phosphatase Activity: Insights from Bacterial Isolates from a Contaminated Subsurface." Environmental Science Technologies.

Belli, K. M., T. J. DiChristina, P. Van Cappellen and M. Taillefert (2015). "Effects of aqueous uranyl speciation on the kinetics of microbial uranium reduction." Geochimica et Cosmochimica Acta 157: 109-124.

Bencheikh-Latmani, R. and J. O. Leckie (2003). "Association of uranyl with the cell wall of Pseudomonas fluorescens inhibits metabolism." Geochimica et Cosmochimica Acta 67(21): 4057-4066.

Bernhard, G., G. Geipel, T. Reich, V. Brendler, S. Amayri and H. Nitsche (2001). "Uranyl(VI) carbonate complex formation: Validation of the Ca2UO2(CO3)3(aq.) species." Radiochimica Acta 89(8/2001).

Brooks, S. C., J. K. Fredrickson, S. L. Carroll, D. W. Kennedy, J. M. Zachara, A. E. Plymale, S. D. Kelly, K. M. Kemner and S. Fendorf (2003). "Inhibition of Bacterial U(VI) Reduction by Calcium." Environmental Science \& Technology 37(9): 1850-1858.

Carvajal, D. A. (2011) "Understanding the Role of the Bacteria, Isolated." FIU Electronic Theses and Dissertations. Paper 459.

Carvajal, D. A., Y. P. Katsenovich and L. E. Lagos (2012). "The effects of aqueous bicarbonate and calcium ions on uranium biosorption by Arthrobacter G975 strain." Chemical Geology 330-331: 51-59. 
Catalano, J. G., J. P. McKinley, J. M. Zachara, S. M. Heald, S. M. Smith and G. E. Brown (2006). "Changes in Uranium Speciation through a Depth Sequence of Contaminated Hanford Sediments." 40 (8): pp 2517-2524.

Donlan, R. M. (2002). "Biofilms: Microbial Life on Surfaces." Emerging Infectious Diseases 8(9): 881-890.

Ejnik, J. W., M. M. Hamilton, P. R. Adams and A. J. Carmichael (2000). "Optimal sample preparation conditions for the determination of uranium in biological samples by kinetic phosphorescence analysis (KPA)." Journal of Pharmaceutical and Biomedical Analysis 24(2): 227-235.

Finch, R. and T. Murakami (1999). Systematics and Paragenesis. URANIUM: Mineralogy, Geochemistry and the Environment III.

Gudavalli, R. K. P., Y. P. Katsenovich, D. M. Wellman, M. Idarraga, L. E. Lagos and B. Tansel (2013). "Comparison of the kinetic rate law parameters for the dissolution of natural and synthetic autunite in the presence of aqueous bicarbonate ions." Chemical Geology 351: 299-309.

Herrera, S. C., V. Anagnostopolous, Y. P. Katsenovich, B. Lee and M. Lee (2016). "The Effect of Bicarbonate on Autunite Dissolution in the Presence of Shewanella oneidensis under Oxygen Restricted Conditions-16429."

Katsenovich, Y., D. Carvajal, R. Guduru, L. Lagos and C.-Z. Li (2013). "Assessment of the Resistance to Uranium (VI) Exposure byArthrobactersp. Isolated from Hanford Site Soil." Geomicrobiology Journal 30(2): 120-130.

Katsenovich, Y. P., D. A. Carvajal, D. M. Wellman and L. E. Lagos (2012). "Enhanced $\mathrm{U}(\mathrm{VI})$ release from autunite mineral by aerobic Arthrobacter sp. in the presence of aqueous bicarbonate." Chemical Geology 308-309: 1-9.

Khemiri, A., M. Carriere, N. Bremond, M. A. Ben Mlouka, L. Coquet, I. Llorens, V. Chapon, T. Jouenne, P. Cosette and C. Berthomieu (2014). "Escherichia coli response to uranyl exposure at low pH and associated protein regulations." PLoS One 9(2): e89863.

Langmuir, D. (1978). "Uranium solution-mineral equilibria at low temperatures with applications to sedimentary ore deposits." Geochimica et Cosmochimica Acta 42(6, Part A): 547-569. 
Lin, H., G. N. Bennett and K. Y. San (2005). "Chemostat culture characterization of Escherichia coli mutant strains metabolically engineered for aerobic succinate production: a study of the modified metabolic network based on metabolite profile, enzyme activity, and gene expression profile." Metab Eng 7(5-6): 337-352.

Lin, X., D. Kennedy, A. Peacock, J. McKinley, C. T. Resch, J. Fredrickson and A. Konopka (2012). "Distribution of microbial biomass and potential for anaerobic respiration in Hanford Site 300 Area subsurface sediment." Appl Environ Microbiol 78(3): 759-767.

McLean, J. S., G. E. Pinchuk, O. V. Geydebrekht, C. L. Bilskis, B. A. Zakrajsek, E. A. Hill, D. A. Saffarini, M. F. Romine, Y. A. Gorby, J. K. Fredrickson and A. S. Beliaev (2008). "Oxygen-dependent autoaggregation in Shewanella oneidensis MR-1." Environ Microbiol 10(7): 1861-1876.

Peterson and S. R. J. Rockhold M.L., Thorne P.D., Williams M.D. (2008, February). "Uranium Contamination in the Subsurface Beneath the 300 Area, Hanford Site,Washington.".

Peterson, R. E., M. L. Rockhold, R. J. Serne, P. D. Thorne and M. D. Williams. (2008, February). "Uranium Contamination in the Subsurface Beneath the 300 Area, Hanford Site,Washington.".

Pinchuk, G. E., O. V. Geydebrekht, E. A. Hill, J. L. Reed, A. E. Konopka, A. S. Beliaev and J. K. Fredrickson (2011). "Pyruvate and lactate metabolism by Shewanella oneidensis MR-1 under fermentation, oxygen limitation, and fumarate respiration conditions." Appl Environ Microbiol 77(23): 8234-8240.

Roberts , J. A., D. A. Fowle, B. T. Hughes and E. Kulczycki (2006). "Attachment Behavior of Shewanella putrefaciens." (23): 631-640.

Sanchez, A. M., G. N. Bennett and K. Y. San (2005). "Novel pathway engineering design of the anaerobic central metabolic pathway in Escherichia coli to increase succinate yield and productivity." Metab Eng 7(3): 229-239.

Sepulveda-Medina, P. (2014). Investigating the Role of a Less Uranium Tolerant. Miami, Florida, USA, FIU Electronic Theses and Dissertations. Paper 1125.

Sheng, L. and J. B. Fein (2013). "Uranium adsorption by Shewanella oneidensis MR-1 as a function of dissolved inorganic carbon concentration." Chemical Geology 358: 15-22. 
Sheng, L. and J. B. Fein (2014). "Uranium reduction by Shewanella oneidensis MR-1 as a function of $\mathrm{NaHCO} 3$ concentration: surface complexation control of reduction kinetics." Environ Sci Technol 48(7): 3768-3775.

Smeaton, C. M., C. G. Weisener, P. C. Burns, B. J. Fryer and D. A. Fowle (2008). "Bacterially enhanced dissolution of meta-autunite." American Mineralogist 93(11-12): 1858-1864.

Thormann, K. M., R. M. Saville, S. Shukla, D. A. Pelletier and A. M. Spormann (2004). "Initial Phases of biofilm formation in Shewanella oneidensis MR-1." J Bacteriol 186(23): 8096-8104.

Wellman, D. M., K. M. Gunderson, J. P. Icenhower and S. W. Forrester (2007). "Dissolution kinetics of synthetic and natural meta-autunite minerals, $\mathrm{X} 3-\mathrm{n}(\mathrm{n})+[(\mathrm{UO} 2)(\mathrm{PO} 4)] 2 \cdot \mathrm{xH} 2 \mathrm{O}$, under acidic conditions." Geochemistry, Geophysics, Geosystems 8(11): n/a-n/a.

Wellman, D. M., J. P. Icenhower, A. P. Gamerdinger and S. W. Forrester (2006). Effects of $\mathrm{pH}$, temperature, and aqueous organic material on the dissolution kinetics of, American Mineralogist.

Wellman, D. M., E. M. Pierce, D. H. Bacon, J. S. Fruchter and V. R. Vermeul. (2009, March 5). "Polyphosphate Remediation Technology for In-Situ Stabilization of Uranium 9093."

Wu, C., Y. Y. Cheng, H. Yin, X. N. Song, W. W. Li, X. X. Zhou, L. P. Zhao, L. J. Tian, J. C. Han and H. Q. Yu (2013). "Oxygen promotes biofilm formation of Shewanella putrefaciens CN32 through a diguanylate cyclase and an adhesin." Sci Rep 3: 1945. 